\title{
CAMA
}

Centre for Applied Macroeconomic Analysis

\section{The stability of tax elasticities over the business cycle in European countries}

\section{CAMA Working Paper 44/2017 July 2017}

\section{Melisso Boschi}

Senate of the Republic of Italy and

Centre for Applied Macroeconomic Analysis, ANU

\section{Stefano d'Addona}

Department of Political Science, University of Roma Tre and

Centre for Applied Macroeconomic Analysis, ANU

\section{Abstract}

We estimate short- and long-run tax elasticities that capture the relationship between changes in national income and tax revenue. We show that the short-run tax elasticity changes according to the business cycle. We estimate a two state Markov-switching regression on a novel dataset of tax policy reforms in 15 European countries from 1980 to 2013, showing that the elasticities during booms and recessions are statistically (and often economically) different. The elasticities of (i) indirect taxes, (ii) social contributions, and (iii) corporate income taxes, tend to be larger during recessions. Tax elasticities for personal income tend to be more stable across the regimes. Estimates of long-run elasticities are in line with existing literature. 


\section{Keywords}

Tax elasticity, Tax policy discretionary change, Business cycle, European economy, Markov-switching regimes

\section{JEL Classification}

C24, C29, E32, E62, H20, H30

\section{Address for correspondence:}

(E) cama.admin@anu.edu.au

ISSN 2206-0332

The Centre for Applied Macroeconomic Analysis in the Crawford School of Public Policy has been established to build strong links between professional macroeconomists. It provides a forum for quality macroeconomic research and discussion of policy issues between academia, government and the private sector.

The Crawford School of Public Policy is the Australian National University's public policy school, serving and influencing Australia, Asia and the Pacific through advanced policy research, graduate and executive education, and policy impact. 


\title{
The stability of tax elasticities over the business cycle in European countries
}

\author{
Melisso Boschi $^{\mathrm{ab}} \quad$ Stefano d'Addona ${ }^{\mathrm{c}}$
}

July 19, 2017

\begin{abstract}
We estimate short- and long-run tax elasticities that capture the relationship between changes in national income and tax revenue. We show that the short-run tax elasticity changes according to the business cycle. We estimate a two state Markov-switching regression on a novel dataset of tax policy reforms in 15 European countries from 1980 to 2013, showing that the elasticities during booms and recessions are statistically (and often economically) different. The elasticities of (i) indirect taxes, (ii) social contributions, and (iii) corporate income taxes, tend to be larger during recessions. Tax elasticities for personal income tend to be more stable across the regimes. Estimates of long-run elasticities are in line with existing literature.
\end{abstract}

Keywords: Tax elasticity, Tax policy discretionary change, Business cycle, European economy, Markov-switching regimes

JEL Classification: C24, C29, E32, E62, H20, H30

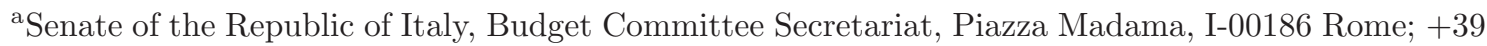
066706 3731; meli.boschi@gmail.com

${ }^{\mathrm{b}}$ Centre for Applied Macroeconomic Analysis (CAMA), Australian National University

${ }^{\mathrm{c}}$ Department of Political Science, University of Roma Tre, Via G. Chiabrera, 199, I-00145 Rome; +39 065733 5331; daddona@uniroma3.it
} 


\section{Introduction}

Estimating the tax elasticity, that is the tax revenue change brought about by a given change in national income, is an essential step of fiscal policy implementation. Governments use the tax elasticity to forecast revenues when preparing their budget and to estimate the cyclical component of the budget balance as a pre-requisite to assess the fiscal stance. Clearly, large forecasting errors lead to budget surprises and inaccurate assessments of the fiscal stance, possibly associated to undue fiscal policy responses. Such an outcome might be especially undesired for European Union members: in the current surveillance framework a significant deviation from the medium term budgetary objective may trigger a specific correction mechanism.

Tax elasticities are estimated using mainly two distinct approaches: The first relies on micro-data and detailed information on the national tax code, while the second is based on econometric techniques. Current practice at international institutions such as the Organization for Economic Cooperation and Development (OECD) or the European Commission (EC) relies heavily on the first approach (see Girouard and André, 2005 for a detailed illustration). The academic literature, on the other hand, has mainly followed the second approach, using econometric techniques to disentangle the long-run tax elasticity, that is how a tax revenue will tend to grow over time as income grows, capturing the potential growth of tax revenue, from the short-run tax elasticity, that is the percent change of the tax revenue in response to a one percent change in income, capturing how tax revenue will fluctuate over the business cycle as income fluctuates. Wolswijk (2009) provides a recent example of this research.

We adopt the second approach, but examine the commonly adopted assumption that the short-run tax elasticity is constant over the business cycle.

The empirical analysis covers 15 European countries: Austria, Belgium, Denmark, Finland, France, Germany, Greece, Ireland, Italy, Netherlands, Norway, Portugal, Spain, 
Sweden, and UK. The data sample is quarterly over the period 1980-2013.

As a first contribution, we propose a regression-based model where short-run tax elasticities are allowed to shift as the economy shifts between booms and recessions, providing an estimate of tax elasticities in each state and showing that their difference across states is statistically significant. In particular, our results show a clear tendency for short-run elasticities of indirect taxes, social contributions, and, to a lesser extent, corporate income taxes to increase during recessions, while results for personal income taxes are not so clear cut. Short-run elasticities' tendency to increase in recession also holds across countries, though less pronouncedly. This is so for 7 out of 15 countries, while elasticities are larger in booms for 4 countries. In the remaining 4 countries no tendency prevails.

There are various theoretical rationales for a time-varying tax elasticity. One motivation concerns composition effects, that is the relative change of tax bases shares of GDP (consumption, wages, asset prices) over the business cycle ${ }^{1}$. Behavioral aspects of taxation also impinge on the variability of tax elasticities. Tax compliance, in fact, is expected to change over the business cycle as taxpayers facing economic downturns are prone to perceive a smaller risk of penalties due to tax evasion as compared to larger potential gains from avoiding bankruptcy (see Brondolo, 2009). Moreover, cyclical economic downturns can push economic activity from the formal to the informal sector. This is consistent with evidence that tax collection efficiency appears to be lower over economic contractions (see Sancak et al., 2010). Income inequality matters as well. As the economy slows down, the lower end of the income distribution bears the largest part of lay-offs, while most income tax revenues come from the higher end of the distribution for which earning and spending patterns remain relatively stable over the business cycle.

\footnotetext{
${ }^{1}$ An example is provided by Larch and Turrini (2009). They show that the increase of tax elasticities with respect to GDP at the end of the 1990s and early 2000s was mainly due to the increased share of consumption in total income in Germany and to a combination of high wage share, rising imports, and high asset prices in France.
} 
We take these concerns seriously and test the stability over the business cycle of shortrun elasticity of selected tax categories (personal income, corporate income, indirect, and social contributions) with respect to their bases (tax-to-base elasticity) along with the elasticity of the same bases with respect to GDP as a proxy for the overall level of income (base-to-GDP elasticity). Following the warnings of Sobel and Holcombe (1996), we also estimate the long-run elasticity and assume that it is immune from regime shifts since it reflects the long-run, potential, relationship between taxes and bases as well as between bases and GDP. We finally combine, both for the long-run and the short-run estimates, the tax-to-base and base-to-GDP elasticities in an overall estimate of tax-to-GDP elasticity.

As a second contribution, this paper proposes a method to deal with the omitted variables bias arising from the effect of discretionary tax policy changes on the relationship between tax revenue and income. Most studies typically tackle this bias by removing the government ex ante estimates of tax policy changes from the tax revenue thus obtaining a time series that only represent the effect of income changes.

The remainder of the paper is organized as follows. In section 2 we illustrate how our econometric methodology allows for an explicit association of estimated regimes to business cycle phases, thus overcoming most of the methodological drawbacks affecting existing attempts to estimate time-varying tax elasticities that we discuss in subsection 2.1. We then discuss how we dealt with the above mentioned omitted variables bias, using a novel approach based on the analysis of the narrative record of European Union member States' tax reforms collected by the European Commission. Section 3 presents the data description and sources, including our choice of proxy for each tax category base. We also illustrate the method we use to make the narrative record of tax reforms operational. In section 4 we discuss our results and how they relate to the existing literature on tax elasticities. Finally, section 5 draws policy implications and concludes. 


\section{Empirical methodology}

Current empirical literature on tax elasticities typically follows a two-step procedure. In the first step, a regression model with log-level variables is estimated to obtain the longrun, potential effect of income changes on tax revenues. Given non-stationarity of the relevant time series, however, the OLS estimates would be asymptotically biased with inconsistent standard errors. To avoid coefficients' bias, the log-level regression model is usually augmented with leads and lags of the growth rate of the independent variable, thereby obtaining the Dynamic Ordinary Least Squares (DOLS) model proposed by Stock and Watson (1993).

Given its ability to accommodate higher orders of integration, and to deal with endogeneity among regressors and serial correlation issues (Koester and Priesmeier, 2012), this estimator has proved to be superior to standard OLS estimates or to Vector Error Correction Mechanism (VECM) models (Johansen, 1995), especially in small samples. Thus, we opted for a DOLS approach in conjunction with the Newey and West (1987) correction to avoid standard errors' inconsistency.

Changes in tax policy also complicate econometric estimates of these tax elasticities. The main challenge derives from a huge omitted variable bias that arises because tax revenue changes are determined not only automatically by changing economic conditions but also by discretionary tax policy changes - legislated changes in tax rates, tax base definitions, and tax administration.

Several studies (see Bettendorf and van Limbergen, 2013, Mourre and Princen, 2015, and Wolswijk, 2009, among others) deal with this bias collecting detailed information on national tax policy changes to quantify and remove from revenues the effect of discretionary measures using the proportional adjustment method proposed by Prest (1962). ${ }^{2}$

\footnotetext{
${ }^{2} \mathrm{~A}$ note on terminology is in order here. Most authors researching tax elasticities call tax revenue changes arising from changing economic conditions endogenous as opposed to revenue changes arising from discretionary tax policy changes, which they call exogenous (see, for example, Princen et al., 2013, p. 11). As argued by Romer and Romer, 2010, however, tax policy changes can be discretionary while
} 
However, as far as we know, tax reform databases for the countries we analyze are unavailable $^{3}$. If one collected this information from national sources, its reliability would be at least subject to skepticism because of cross-country differences in tax codes and tax reforms classification methods ${ }^{4}$. Moreover, as clearly shown by Barrios and Fargnoli (2010), comparability across countries is also limited by differences in accounting rules (accrual versus cash basis of accounting), or in the very definition of discretionary measure (based on a "no-policy change" versus current legislation assumption).

Finally, we should bear in mind that discretionary measures represent ex ante government estimates of the revenue effect of tax policy changes rather than ex post realizations, heavily relying on the accuracy of financial and macroeconomic baselines and forecasts. ${ }^{5}$ We thus contribute to the literature by suggesting an alternative approach to deal with this omitted variables bias that relies on qualitative information provided by a narrative record of the tax policy changes taken in European countries ${ }^{6}$. For each tax category and each country, we codify a series of quarterly indicator variables to record when a tax policy change takes effect. This way of considering tax reforms in regression models avoids all problems discussed above since it is unaffected by differences in accounting rules or reforms definition, as well as accuracy of forecasts of reforms effects, though, as it is obvious, it does not allow to account for different sizes of discretionary changes.

Therefore, for each tax category we estimate the following long-run DOLS model of

being endogenous at the same time. They can be taken, in fact, in response to business cycle conditions or to finance public expenditures, so that they are systematically correlated with output - and are in this sense endogenous. This is why we reckon the term automatic as opposed to discretionary tax policy changes more appropriate than endogenous.

${ }^{3}$ We are indeed aware of one such database at annual frequency developed by the European Commission and based on information on discretionary measures collected through questionnaires sent out to EU Member States in the context of the Output Gap Working Group (OGWG) of the Economic Policy Committee, covering a large sample of EU countries (see Barrios and Fargnoli, 2010 and Princen et al., 2013 for an analytical description). Mourre and Princen (2015) use it to analyze tax elasticities in the European Union. Unfortunately, this database is unavailable to the public.

${ }^{4}$ In fact, we are able to use this approach in a companion paper that focuses on Italy. See Boschi et al., 2017.

${ }^{5}$ Such estimates depend on a number of crucial assumptions about the fiscal multiplier, the effect of tax reforms on the bases, the informal sector, the tax compliance, and so forth.

${ }^{6}$ This narrative approach is much in the spirit of Ramey and Shapiro (1998). 
revenue:

$$
\log T_{t}=\theta^{T B}+\delta^{T B} \log B_{t}+\sum_{j=-k}^{k} \phi_{1 j}^{T B} \Delta \log B_{t+j}+\phi_{2}^{T B} D_{t}^{T}+\gamma_{t}^{T B}
$$

where $T_{t}$ and $B_{t}$ are the tax revenue and base in year $t$ respectively, $\theta^{T B}$ is a constant, $D_{t}^{T}$ is the tax policy intervention dummy, $\gamma_{t}^{T B}$ is an error term, and $\delta^{T B}$ is the long-run tax-to-base elasticity.

Next, we estimate the same regression model but with variables taken in first logdifferences to gauge the short-run tax elasticity, that is the percentage change in tax revenue associated to a percent change in base. It is well known that estimates from this specification could be biased if the variables are cointegrated. To overcome this problem, we follow the common practice (e.g. Bettendorf and van Limbergen, 2013, Bouthevillain et al., 2001, Sobel and Holcombe, 1996, Wolswijk, 2009) and include lagged residuals of the long-run regression model among the regressors, thereby obtaining an error-correction model (ECM).

The main novelty of this paper consists of accounting for business cycles in the shortrun regression model to capture the possible nonlinear relationship between tax revenues and income. To do so we model the underlying economy as a Markov process that switches between two states $(s)$ the first characterized by a high growth rate of output ("boom", b) and the second by a low growth rate of output ("recession", $r$ ),

We thus estimate the above short-run tax-to-base elasticity model conditioning on the state of the economy $s_{t}=b, r$ at time t:

$$
\Delta \log T_{t}=\alpha^{T B}\left(s_{t}\right)+\beta^{T B}\left(s_{t}\right) \Delta \log B_{t}+\lambda^{T B}\left(s_{t}\right) \gamma_{t-1}^{T B}+\phi_{3}^{T B}\left(s_{t}\right) D_{t}^{T}+\varepsilon_{t}^{T B}
$$

where all coefficients, including the tax revenue short-run elasticity, $\beta^{T B}$, are conditional on the economy state $\left(s_{t}\right)$, and $\varepsilon_{t}^{T B}$ is an error term. 
Two short-run effects are captured in any time period: tax revenues can respond to changes in the tax base as well as to the long-run disequilibrium between revenue and base that exists at the beginning of the period.

Since we are ultimately interested in estimating the tax revenue elasticity with respect to income, we need to take into account the likely fluctuation of the relevant tax base with respect to income. Hence, we proceed in the same way as above for the tax base by first estimating:

$$
\log B_{t}=\theta^{B Y}+\delta^{B Y} \log Y_{t}+\sum_{j=-k}^{k} \phi_{1 j}^{B Y} \Delta \log Y_{t+j}+\phi_{2}^{B Y} D_{t}^{T}+\gamma_{t}^{B Y}
$$

where $Y_{t}$ is the income, or GDP, level in year $\mathrm{t}$ and $\delta^{B Y}$ is the long-run base-to-GDP elasticity.

Then we feed the lagged error term $\gamma_{t-1}^{B Y}$ into the regression model with log-differenced variables to obtain:

$$
\Delta \log B_{t}=\alpha^{B Y}\left(s_{t}\right)+\beta^{B Y}\left(s_{t}\right) \Delta \log Y_{t}+\lambda^{B Y}\left(s_{t}\right) \gamma_{t-1}^{B Y}+\phi_{3}^{B Y}\left(s_{t}\right) D_{t}^{T}+\varepsilon_{t}^{B Y}
$$

where all coefficients are conditional on the state of the economy, and $\beta^{B Y}$ is the short-run base-to-GDP elasticity.

The overall elasticity of the tax revenue with respect to income - the tax-to-GDP elasticity - is given by (see Perotti, 2005 and Girouard and André, 2005 for a formal derivation):

$$
\delta^{T Y}\left(s_{t}\right)=\delta^{T B}\left(s_{t}\right) \times \delta^{B Y}\left(s_{t}\right)
$$

and

$$
\beta^{T Y}\left(s_{t}\right)=\beta^{T B}\left(s_{t}\right) \times \beta^{B Y}\left(s_{t}\right)
$$


We therefore obtain, for each tax category, one tax-to-GDP elasticity for each state of the economy ("boom" or "recession").

As a point of comparison, we also estimate short-run linear elasticities for tax-to-base and base-to-GDP, and then combine them in a tax-to-GDP estimate.

\subsection{Regime estimation}

Only a few studies, using a variety of econometric methodologies, devote the deserved attention to time-varying tax elasticities. Bruce et al. (2006) use an ECM model to estimate long-run and short-run elasticities of personal income and sales taxes in the United States allowing for asymmetric deviations of short-run values from the long-run equilibrium. They find asymmetric behavior in most of the 50 states. Wolswijk (2009) focuses on the Netherlands because of the availability of data on tax revenues net of the effect of discretionary measures. He estimates a regression model of tax revenues on their bases allowing for asymmetric effects of deviations from the long-run equilibrium. Estimates for five tax categories confirm significant differences between short-run and long-run tax-to-base elasticities, especially over economic downturns, with evidence of asymmetric behavior. Poghosyan (2011) estimates rolling regressions to quantify short-run tax elasticities of five tax categories with respect to their bases, using a panel model to compare short-run and long-run elasticities of Lithuania to that of ten new EU members. His contribution confirms the importance of allowing for cyclical differences in tax elasticities. Similar evidence is found for South Africa by Jooste and Naraidoo (2011) using a smooth transition regression model.

To estimate time-varying tax elasticities we use the methodology proposed by d'Addona and Musumeci $(2013)^{7}$ and model an economy where output switches between two (unobservable) states: a high mean state ("boom") and a a low mean state ("recession"). Since

\footnotetext{
${ }^{7}$ See Boschi et al. (2012) for an extension to a multivariate model.
} 
agents (e.g. taxpayers) cannot observe the state of the economy, they infer the probability of being in a particular state by looking at the output growth rate realizations, which therefore acts as a state signal. We indicate the latent state of the economy by $s_{t}$ and assume that it follows a hidden Markov chain with transition probabilities matrix $P$ (see Hamilton, 1989).

Specifically, we model the output growth rate as a regime-dependent process in its mean with i.i.d. normal innovations:

$$
\Delta \log Y_{t}=\mu\left(s_{t}\right)+\epsilon_{t}
$$

where $\mu$ is the mean of the process conditional on the unobservable state of the economy $s_{t}$ and $\epsilon_{t}$ is a random Gaussian shock with standard deviation $\sigma$. Through the observation of the realizations of $\Delta \log Y_{t}$, agents infer the underlying state of the economy by formulating the posterior probability of being in each state of the economy based on information available up to time $t$ and on knowledge of the population parameters. Hence, the filtered posterior probability is:

$$
\widehat{\xi}_{t \mid t}=\operatorname{Pr}\left\{s_{t}=s \mid \Omega_{t}\right\}
$$

where $s$ identify the state of the economy (andfor boom and recession respectively), and $\Omega_{t}$ denotes the information set including all data and parameters up to time $t$. Agents update their beliefs according to:

$$
\widehat{\xi}_{t \mid t}=\frac{\widehat{\xi}_{t \mid t-1} \otimes \zeta_{t}}{1^{\prime}\left(\widehat{\xi}_{t \mid t-1} \otimes \zeta_{t}\right)}
$$

where $\otimes$ indicates the element-by-element product, 1 denotes a vector of ones whose dimension corresponds to the number of states, and $\zeta_{t}$ is a vector of Gaussian density functions of output growth rates conditional on the state $s_{t}$ : 


$$
\zeta_{t}=\left[\begin{array}{l}
f\left(\Delta \log Y_{t} \mid s_{t}=b, \Omega_{t-1}\right) \\
f\left(\Delta \log Y_{t} \mid s_{t}=r, \Omega_{t-1}\right)
\end{array}\right]
$$

with the density of $\Delta \log Y_{t}$ conditional on the state $s_{t}$ defined as:

$$
f\left(\Delta \log Y_{t} \mid s_{t}=s, \Omega_{t-1}\right)=\frac{1}{\sqrt{2 \pi \sigma}} \exp \left\{\frac{-\left(\Delta \log Y_{t}-\mu\left(s_{t}\right)\right)^{2}}{2 \sigma^{2}}\right\}
$$

For each country, we first obtain the posterior probability, $\widehat{\xi}_{t \mid t}$, of the economy being in each state at time $t$ by estimating the regime-switching model using a Markov Chain Monte Carlo (MCMC) procedure that closely follows the algorithm described in section 9.1 of Kim and Nelson (1999). We then estimate the long-run regression model for each tax category. Finally, we estimate the short-run regression model by maximum likelihood using the MCMC probabilities as weights for the regression in each state of the economy. Specifically, we maximize $\ln L$ with

$$
L=\prod_{t}^{T} \widehat{\xi}_{t \mid t}^{s}\left\{\frac{1}{\sqrt{\pi \sigma_{s}^{2}}} \exp \left[\left(Z_{t}-\widehat{C}^{s} X_{t}\right)\left(Z_{t}-\widehat{C}^{s} X_{t}\right)^{\prime} / 2 \sigma_{s}^{2}\right]\right\}
$$

where $Z_{t}$ indicates the short-run model dependent variable (tax revenue or base), $\widehat{C}^{s}$ indicates the vector of coefficients to be estimated, and $X_{t}$ is the vector of regressors (base or GDP with leads and lags).

We follow the above procedure to obtain the tax-to-base and base-to-GDP elasticities.

It is worth noting that in the literature reviewed above asymmetric behavior is conceived with respect to a reference term, like the long-run equilibrium, and therefore is not necessarily associating the tax elasticity with business cycle phases. Others, like, for example, Bettendorf and van Limbergen (2013), look at asymmetric deviations with respect to the output gap as an indicator of the business cycle, but such association is deterministic rather than stochastic. A similar deterministic analysis is implemented by 
Princen et al. (2013), who compare elasticities computed at each of the sample years to examine behavior over the business cycle. We emphasize that our methodology, instead, results in a close association of the two short-run elasticities with the business cycle phases and, most importantly, such association is stochastic in nature since it is obtained by weighting upon the posterior probability of the economy being in a boom or in a recession. This represents a significant methodological improvement with respect to the existing literature.

Furthermore, in comparison to Princen et al. (2013), our method is operationally more useful since it might be easily incorporated in surveillance and forecasting activity. In fact, we estimate one short-run elasticity that holds for all boom periods over the sample, and one for all recession periods, while Princen et al. (2013) estimate a different elasticity for every and each sample year. Princen et al. (2013) themselves acknowledge that their elasticities are difficult to interpret and highly erratic.

\section{Data}

Data are quarterly over the period 1980q1-2013q1, though the sample range changes across countries and tax categories depending on the minimum available length of time series for each country (see table 14). We use two sources: The Organization for Economic Co-operation and Development (OECD) quarterly sector accounts Data Warehouse and the European Central Bank (ECB) Data Warehouse. Except where indicated, data from the OECD and the ECB come originally at current prices, in millions of national currency. Where necessary, data are seasonally adjusted using the TRAMO/SEATS programs (see Gómez and Maravall, 1996). Data are also deflated using the indicated, appropriate, deflator to render them in real terms. The Appendix reports a detailed description of data sources, definitions, and manipulation. 


\section{Results}

A preliminary analysis of all the time series involved indicates that all variables can be reasonably considered to be driven by I(1) or I(2) stochastic trends, which justifies the use of DOLS and ECM methodologies ${ }^{8}$. For each country and each tax category we estimate the long-run DOLS model as well as the short-run regimes switching ECM regression, both for the tax-to-base and the base-to-GDP model ${ }^{9}$. We then combine the estimated values to obtain a single tax-to-GDP elasticity for each country and each tax category. The number of leads and lags in the DOLS model are chosen according to the Akaike Information Criterion (AIC) and the Schwarz information criterion (SIC). As detailed in Appendix, the tax reform dummy variables are coded so that they take value one when reforms become law and start exerting their effects. However, because reforms start to be discussed earlier than they take place and usually take time to be implemented, people can develop expectations on them and modify their behavior much before reforms become law. We test this hypothesis by estimating two versions of each model - one version includes the dummy variable with no leads and another version, under the hypothesis of reforms foresight, includes the dummy variable with a lead. The AIC and SIC are used to choose between the two model specifications. When the criteria results for the revenue-to-base elasticity differ from those for the base-to-GDP elasticity model, we choose the model that gives the largest criterion improvement ${ }^{10}$.

Generally speaking, one result holds across all countries and tax categories - nonlinearity is always statistically significant, as shown by the likelihood ratio tests (LR) statistics and small $p$-values, ${ }^{11}$ though the difference between the boom and recession short-run

\footnotetext{
${ }^{8}$ Unit root test results are available upon request.

${ }^{9}$ Long-run estimation were also performed using GLS regressions by which similar results were obtained.

${ }^{10}$ These results are available upon request.

${ }^{11}$ We test for regime invariance through a likelihood ratio (LR) test with statistic

$$
\lambda_{L R}=2\left[\ln L(\tilde{\delta})-\ln L\left(\tilde{\delta}_{r}\right)\right]
$$


elasticities is not always economically relevant. ${ }^{12}$

Personal income tax (PIT). The tax-to-base elasticities for PIT are reported in table 1. The long-run elasticity ranges from 0.1 percent in Portugal to almost 3 percent in Germany. The short-run, linear, elasticity is much lower than the long-run one, except for Austria, Denmark, Italy, Portugal, and Spain, and more imprecisely estimated, as shown by the large standard errors. Nonlinearity is statistically significant for all countries, with a varying difference between the elasticity in booms and in recessions - it ranges from more than 3.30 in Austria to 0.13 in Germany. The short-run linear elasticity always lies within the boom and the recession elasticities, except for Germany and Spain. It is unclear whether the short-run elasticity increases or not in recession - it increases in 8 countries, but declines in the remaining 6. The Markov-switching models, however, fit the data at varying degrees depending on the country - $R^{2}$ ranges from 0.04 for France to 0.61 for Austria. Koester and Priesmeier (2012) report a long-run elasticity for German PIT much smaller than our estimate (1.75 versus 2.99 ), while the opposite is true for the short-run linear elasticity (1.41 versus 0.93). Regarding the Netherlands, Wolswijk (2009) estimates a long-run PIT elasticity similar to ours (1.57 versus 1.32); his short-run estimate amounts to 1.89, while ours is 1.06 . Wolswijk (2009) does not find any evidence of asymmetry around the trend value, while in our model the nonlinear short-run elasticity shifts from 0.40 in booms to 1.29 in recessions. Our short-run results for the Netherlands are more in line with Bettendorf and van Limbergen (2013), who also obtain a value of 1.07, while their long-run PIT elasticity is 0.89 .

As for the base-to-GDP elasticities reported in table 2, the long-run elasticity is generally larger than the short-run one for almost all countries, except Norway, Spain, and where $\tilde{\delta}$ is the unconstrained maximum likelihood estimator and $\tilde{\delta}_{r}$ is the constrained estimator obtained by maximizing the likelihood function under the null hypothesis $H_{0}$ of tax elasticity regime invariance. Under $H_{0}, \lambda_{L R}$ has an asymptotic $\chi^{2}$ distribution with degrees of freedom equal to the number of restrictions.

${ }^{12}$ Notice that the two-steps estimation procedure reduces the test power for nonlinearity, whose results tend thus to be conservative. 
UK, although the only large difference is recorded for Norway. The variability of the longrun elasticity is smaller than that of the tax-to-base elasticity and, if we abstract from Norway for which we obtain almost zero, it goes from 0.81 for Sweden to 1.8 for Portugal. Nonlinearity is statistically significant for all countries with the difference between boom and recession elasticities varying between 0.02 for the Netherlands to more than 1 for the UK, excluding Norway for which such difference is implausibly large. The short-run linear elasticity lies within the nonlinear ones for all countries. For 10 countries out of 14, the PIT base-to-GDP short-run elasticity increases in booms with respect to recessions, giving a neater message than for the tax-to-base elasticity.

Combining the tax-to-base and base-to-GDP elasticities as discussed in subsection 2.1, we obtain the PIT tax-to-GDP elasticity measure shown in table 3. The short-run elasticity is larger in booms for 7 out of 14 countries, it is larger in recessions for 6 countries, while it remains the same across business cycle phases for Greece. Changes across regimes are due to revenues for 8 out of 14 countries: Austria, Denmark, Finland, France, Germany, Greece, Ireland, and the Netherlands, while it is mostly due to bases in the remaining 6 countries (Italy, Norway, Portugal, Spain, Sweden, and UK). We can compare long-run tax-to-GDP results with the elasticity of revenues with respect to the output gap used within the European Union framework for fiscal surveillance of member states (see, for example, Mourre et al., 2013, table A.1, p. 30). We find elasticities that are smaller than the EU ones for 7 out of 14 countries, while they are larger in 4 cases. Long-run PIT elasticities for Finland (0.84) and UK (1.20) are similar to the EU elasticities (0.91 and 1.18).

Corporate income tax (CIT). Table 4 reports the corporate tax-to-base elasticity. Most long-run elasticities, $\delta^{T B}$, are estimated to be around 1, except for France, Greece, Spain, and UK, for which the null hypothesis of this coefficient being 1 is strongly rejected. Short-run linear elasticities, $\beta^{T B}$, are generally smaller than the long-run ones and almost all have large standard errors. The estimate for France is exceptionally large 
(and much larger than the long-run one) and very precisely estimated. Most other coefficients, though, are lower than one. As for the PIT case, nonlinearity in short-run elasticities is strongly supported by the likelihood-ratio tests, and in most countries Finland, France, Germany, Italy, Spain, Sweden, and UK - the difference between booms and recessions is economically relevant. Except for Germany, the short-run linear elasticity of all countries lies between the boom and recession ones. For 5 out of 10 countries the recession elasticity is larger than the boom one, while for 4 countries the opposite is true. Greece reports both elasticities at zero. Koester and Priesmeier (2012) estimate a long-run profit taxes elasticity in Germany around half what we find (0.77 versus 1.54), while their short-run elasticity is larger than ours (0.43 versus 0.15$)$, though within our nonlinear range. Our short-run model for Germany, however, produces so large standard errors that the elasticity estimate results unreliable.

The estimates of the CIT base-to-GDP elasticities reported in table 5 are generally more precise than the tax-to-base ones, as shown by the small standard errors and by the $R^{2}$ values of the Markov-switching models. The long-run elasticities, $\delta^{T B}$, are estimated to be equal or larger than 3 for 6 out of 11 countries, while they are larger than 2 for Austria and Finland. The elasticities of Greece and Spain are not statistically different from 1. The short-run linear elasticities are large as well, for all countries being larger than 2 (except Greece), and for 5 countries being larger than 3. Short-run nonlinearity is strongly supported by the likelihood ratio test and the difference between the two regimes' elasticities is relevant for almost all countries except Greece, Ireland, and Portugal. The recession elasticities are larger than the boom ones in 9 out of 11 countries, but are smaller for Austria. The difference is null for Greece, for which all short-run elasticities are not statistically different from zero.

Table 6 reports the overall tax-to-GDP elasticities. It shows elasticities during recessions larger than during booms in 5 out of 11 countries only, an ambiguity also revealed by the comparison of the long-run and short-run elasticities. Changes across regimes are 
mostly due to revenues for 4 out of 10 countries (Finland, France, Ireland, and Sweden) while they are mostly due to bases for 5 countries (Germany, Italy, Portugal, Spain, Sweden, and UK). In Greece the shift is almost null. In comparison to the estimates used within the EU fiscal surveillance framework (see Mourre et al., 2013, table A.1, p. 30), our long-run tax-to-GDP elasticities are larger in 8 out of 10 countries, while they are smaller in the remaining 2 countries. The difference appears relevant in most cases, except in France and in Ireland.

Indirect tax (IND). The tax-to-base elasticities for indirect taxes are reported in table 7. Long-run elasticities range from the statistically close to zero estimates of Belgium, France, and Germany, to the large values of Italy (2.75) and Sweden (6.36). For Austria, Greece, Spain, and weakly for Finland we could not reject the null hypothesis that the elasticity is equal to one. The short-run linear elasticity is estimated to be lower than the long-run one for 8 out of 14 countries, with larger standard errors. Nonlinearity is statistically significant for all countries, with large LR statistics and $p$-values close to zero. The linear short-run elasticity always lies between the boom and recession ones, except for Greece, whose large standard errors, however, renders such comparison not meaningful. The differences between boom and recession short-run elasticities are almost always economically relevant, going from a minimum of 0.01 for Greece to 1.56 for Austria. As for the PIT case, Austria shows the largest difference between elasticities across regimes. The short-run elasticity is larger in recessions than in booms for all countries except Austria and Germany, with the largest increase from booms to recessions recorded for the UK. The Markov-switching models $R^{2}$ ranges from less than 0.10 for Italy and Sweden to more than 0.40 for Portugal and the Netherlands. Koester and Priesmeier (2012) estimate a long-run elasticity for German VAT with respect to base of 0.79, while our estimate is close to zero. By contrast, their short-run elasticity estimate of 0.90 is almost identical to our result (0.88).

For the Netherlands, Wolswijk (2009) estimates a VAT long-run elasticity of 0.90 along 
with two short-run values -0.64 below the long-term level and 1.10 above the long-term level. Similarly, Bettendorf and van Limbergen (2013) estimate for the same country a long-run elasticity slightly less than one with respect to the consumption base, while the short-run value is larger but still close to one. These authors' VAT short-run elasticities range between 1.186 in good times and 0.709 in bad. Our results, instead, suggest a 1.38 long-run elasticity, while short-run elasticities are unreliably estimated. Nonlinearity is nevertheless strongly supported by the LR test.

The variability of IND base-to-GDP elasticities is lower than the tax-to-base ones (see table 8). Coefficients vary from 0.31 in Austria to 1.19 for the UK. The short-run linear elasticity is lower than the long-run estimate for 12 out of 15 countries, and in between the short-run Markov-switching elasticities for all countries except Denmark. The baseto-GDP estimations are generally more precise than the tax-to-base ones, as shown by the lower standard errors. Short-run elasticities are generally nonlinear, as suggested by the large LR statistics, although the difference between booms and recessions appears lower than the tax-to-base case and in line with the PIT base-to-GDP results. The largest difference is around 0.42 for Germany. The boom elasticities are larger than the recession ones in 7 out of 15 countries. Notice, finally, that most base-to-GDP elasticities in the long-run and, especially so in the short-run, are smaller than one, showing evidence in favor of consumption smoothing. The 8 countries in which recession elasticities are smaller than boom ones, show evidence of a lower consumption smoothing in bad times, potentially due to consumers' desire to stay afloat at a preferred consumption level.

Tax-to-GDP elasticities are larger in booms than in recessions for 9 out of 14 countries, as shown in table 9, with the largest difference obtained for Italy, the Netherlands, and Sweden. Changes across regimes are mostly due to revenues for almost all available countries' estimates, with the exception of Germany. Our tax-to-GDP elasticities are lower than 1 - the value assumed within the EU budgetary surveillance framework (Mourre et al., 2013, table A1, p. 30) - in 8 out of 14 countries, and larger in the remaining 6 
countries.

Social contributions (SC). ${ }^{13}$ Table 10 reports the elasticities of social contributions revenues with respect to their base. Long-run SC tax-to-base elasticities are remarkably stable across most countries, ranging from 0.80 (Finland) to 1.53 (Portugal and UK). The majority of the estimates are close to 0.80. The exceptions are Belgium, Germany, and the Netherlands, whose values are around 0.45 . The short-run linear elasticity is lower than the long-run one for 8 out of 13 countries. Nonlinearity is statistically significant, with large LR statistics and close to zero $p$-values. The linear elasticity always lies between the boom and recession ones. The difference between the boom and the recession shortrun elasticities is almost always economically relevant, going from a minimum of 0.01 in Portugal to almost 6 in the Netherlands. The short-run elasticity is larger in recessions than in booms for 8 out of 13 countries. The Markov-switching models $R^{2}$ ranges from less 0.17 for Germany to 0.63 for Finland

With regards to the SC base-to-GDP elasticities (see table 11) the long-run coefficients vary from 0.0 in Austria to 1.22 in Portugal. The short-run linear elasticity is lower than the long-run one for all countries except the Netherlands and Spain, and always in between the short-run Markov-switching elasticities for all countries, except Finland and Spain. The base-to-GDP estimations are generally more precise than the tax-to-base ones, as indicated by the lower standard errors. Short-run elasticities are generally nonlinear, as suggested by the large LR statistics. The difference between booms and recessions appears to be generally lower than the tax-to-base case. The largest difference is around 0.44 for the Netherlands. The boom elasticities are larger than the recession ones in 5 out of 13 countries.

Tax-to-GDP elasticities are larger in booms than in recessions for 8 out of 13 countries, as shown in table 12, with the largest differences obtained for Denmark, the Netherlands,

\footnotetext{
${ }^{13}$ Notice that in models for Greece, Italy, and Spain, discretionary tax reforms dummy were not included because of multicollinearity due to value one occurring only once.
} 
and the UK. Changes across regimes are mostly due to revenues for almost all countries, except for Ireland, Portugal, and UK. Our estimates of long-run tax-to-GDP elasticities are generally lower than those used by the EU Commission (Mourre et al., 2013, table A1, p. 30), the only exceptions being those of Ireland, Portugal, and UK.

Summary of short-run nonlinearity results. We summarize results on shortrun tax elasticity nonlinearity - our main focus in this paper - in table 13. Results on nonlinearity may either be summarized across tax categories or countries. Across tax categories, we notice a clear tendency for short-run elasticities to increase in recessions with respect to booms. This happens for indirect taxes, social contribution, and, to a lesser extent, for corporate income tax, while for personal income tax the larger elasticities are evenly distributed between booms and recessions. Across countries, results are less clear cut but still show a tendency for larger elasticities in recessions to prevail. This is so for 7 out of 15 countries (Austria, Finland, France, Greece, the Netherlands, Sweden, and UK), while short-run elasticities tend to be larger in booms for 4 countries (Germany, Ireland, Norway, and Portugal). In the remaining 4 countries (Belgium, Denmark, Italy, and Spain) the number of elasticities that are larger in booms equals the number of those larger in recessions. We need, however, to bear in mind that for some countries estimates could not be obtained for all tax categories (Austria, Belgium, Denmark, the Netherlands, Norway, and Sweden).

\section{$5 \quad$ Policy implications and conclusion}

In this paper we present estimates of long-run and short-run elasticities of tax revenues with respect to their bases and of bases with respect to GDP for the main tax categories - personal income taxes, corporate income taxes, indirect taxes, social contributions for a large selection of European Union countries. We propose a method to estimate 
short-run elasticities that vary with country's business cycle. This method consists of a Markov-switching model by which an economy's output switches between two (unobservable) states: a high mean state ("boom") and a low mean state ("recession"). Since agents (e.g. taxpayers) cannot observe the state of the economy, they infer the probability of being in a particular state by looking at the output growth rate realizations, which therefore acts as a state signal. Through the observation of the realizations of output growth, agents infer the underlying state of the economy by formulating the posterior probability of being in each state of the economy. The short-run regression model is then estimated by maximum likelihood using the probabilities as weights for the regression in each state of the economy. As a second contribution, we propose a simple method to take account of discretionary tax measures when estimating tax elasticities. We construct a database of dummy variables that take value one when a tax reform is implemented, and zero otherwise, based on information collected and processed by the European Commission in the annual survey of taxation trends in the European Union. With regard to the main interest of this paper - the variability of short-run tax elasticities over the business cycle - our results across tax categories indicate a clear tendency for short-run elasticities to increase in recessions with respect to booms. This holds for indirect taxes, social contributions, and, to a lesser extent, for corporate income taxes, while for personal income tax the larger elasticities are evenly distributed between booms and recessions. Results are confirmed across countries, with a tendency for larger elasticities in recessions to prevail. This is so for 7 out of 15 countries (Austria, Finland, France, Greece, the Netherlands, Sweden, and UK), while short-run elasticities tend to be larger in booms for 4 countries (Germany, Ireland, Norway, and Portugal). In the remaining 4 countries (Belgium, Denmark, Italy, and Spain) the number of elasticities that are larger in boom equals the number of those that are larger in recession. Our results have potentially important policy implications for the European Union's fiscal surveillance. The current EU framework requires the estimation of a cyclically-adjusted budget balance, i.e. a budget balance based on discretionary fiscal 
policy measures, net of the influence of the business cycle on revenues and expenditure. Computing the cyclically-adjusted budget balance relies on tax revenues elasticities with respect to the output gap and the current procedure uses long-run elasticity estimates. Our results show that tax elasticities themselves change over the business cycle, with a clear tendency to increase in recessions relative to booms. In the same direction point results by Princen et al. (2013), whose estimation method, however, gives highly erratic elasticities. Our method, by contrast, result in only two short-run elasticities, one for boom and another for recession periods, which might therefore be easily incorporated in the cyclically-adjusted computation procedure. In more general terms, our results shed light on one important feature of the tax system. In countries and for tax categories where elasticities increase in recession, a better automatic stabilization role is exerted by the tax system since revenues tend to increase more than proportionately than output, net of discretionary fiscal policy interventions (Belinga et al., 2014).

\section{Acknowledgments}

We would like to thank participants at the 7th CGBCR Conference, University of Manchester, 2014 and the XVII SIEP Conference, University of Ferrara, 2015 for helpful comments on previous versions of this paper. The views here expressed do not necessarily reflect those of the Senate of the Republic of Italy. 
Table 1: Elasticity of PIT revenue with respect to its base

\begin{tabular}{|c|c|c|c|c|c|c|}
\hline \multirow[t]{2}{*}{ Country } & \multirow[t]{2}{*}{$\begin{array}{l}\text { LR elasticity } \\
\delta^{T B} \\
\text { (s.e.) } \\
\end{array}$} & \multirow[t]{2}{*}{$\begin{array}{c}\text { SR linear elasticity } \\
\beta^{T B} \\
\text { (s.e.) }\end{array}$} & \multicolumn{2}{|c|}{$\begin{array}{l}\text { SR MS elasticity } \\
\beta^{T B} \\
\text { (s.e.) }\end{array}$} & \multirow[t]{2}{*}{$\begin{array}{c}\text { MS model } \\
R^{2}\end{array}$} & \multirow[t]{2}{*}{$\begin{array}{c}\text { Likelihood ratio } \\
\text { test statistic } \\
\text { [p-value] }\end{array}$} \\
\hline & & & Boom & Recession & & \\
\hline Austria & $\begin{array}{l}0.39_{\star \star} \\
(0.23)\end{array}$ & $\begin{array}{c}0.46 \\
(0.41)\end{array}$ & 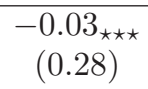 & $\begin{array}{c}3.31^{*} \\
(1.68)\end{array}$ & 0.61 & $\begin{array}{c}166 \\
{[0.00]}\end{array}$ \\
\hline Belgium & - & & - & - & - & - \\
\hline Denmark & $\begin{array}{c}0.30_{\star \star * *}^{* * *} \\
(0.10)\end{array}$ & $\begin{array}{c}0.67_{\star \star}^{* * *} \\
(0.15)\end{array}$ & $\begin{array}{c}0.53_{\star \star \star}^{* * *} \\
(0.17)\end{array}$ & $\begin{array}{c}0.80^{* * *} \\
(0.23)\end{array}$ & 0.47 & $\begin{array}{c}200 \\
{[0.00]}\end{array}$ \\
\hline Finland & $\begin{array}{c}1.39^{* * *} \\
(0.28)\end{array}$ & $\begin{array}{l}0.48_{\star \star \star}^{* *} \\
(0.24)\end{array}$ & $\begin{array}{l}0.40_{\star \star}^{*} \\
(0.22)\end{array}$ & $\begin{array}{c}0.92 \\
(0.68)\end{array}$ & 0.47 & $\begin{array}{c}174 \\
{[0.00]}\end{array}$ \\
\hline France & $\begin{array}{c}2.03_{\star \star}^{* * *} \\
(0.52)\end{array}$ & $\begin{array}{c}0.46 \\
(0.56)\end{array}$ & $\begin{array}{c}0.23 \\
(0.47)\end{array}$ & $\begin{array}{c}1.12 \\
(0.88)\end{array}$ & 0.04 & $\begin{array}{c}430 \\
{[0.00]}\end{array}$ \\
\hline Germany & $\begin{array}{c}2.99_{\text {}}^{* * *} \\
(0.37)\end{array}$ & $\begin{array}{c}0.93^{* * *} \\
(0.22)\end{array}$ & $\begin{array}{c}0.93^{* * *} \\
(0.21)\end{array}$ & $\begin{array}{l}0.80^{*} \\
(0.47)\end{array}$ & 0.41 & $\begin{array}{c}223 \\
{[0.00]}\end{array}$ \\
\hline Greece & $\begin{array}{c}0.54_{\star \star}^{* * *} \\
(0.18)\end{array}$ & 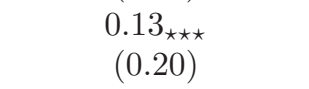 & 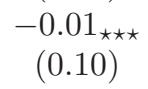 & $\begin{array}{c}0.40 \\
(0.59)\end{array}$ & 0.21 & $\begin{array}{c}128 \\
{[0.00]}\end{array}$ \\
\hline Ireland & $\begin{array}{c}0.68_{\star \star *}^{* * *} \\
(0.13)\end{array}$ & $\begin{array}{c}0.30 \\
(0.43)\end{array}$ & $\begin{array}{c}0.53 \\
(0.87)\end{array}$ & $\begin{array}{l}0.24_{\star} \\
(0.44)\end{array}$ & 0.29 & $\begin{array}{c}111 \\
{[0.00]}\end{array}$ \\
\hline Italy & $\begin{array}{l}0.31_{\star \star} \\
(0.29)\end{array}$ & $\begin{array}{c}0.40 \\
(0.42)\end{array}$ & $\begin{array}{c}0.45 \\
(0.49)\end{array}$ & $\begin{array}{c}0.27 \\
(0.57)\end{array}$ & 0.19 & $\begin{array}{c}176 \\
{[0.00]}\end{array}$ \\
\hline Netherlands & $\begin{array}{l}1.32^{* *} \\
(0.50)\end{array}$ & $\begin{array}{c}1.06 \\
(1.06)\end{array}$ & $\begin{array}{c}0.40 \\
(0.67)\end{array}$ & $\begin{array}{c}1.29 \\
(1.94)\end{array}$ & 0.17 & $\begin{array}{c}72 \\
{[0.00]}\end{array}$ \\
\hline Norway & $\begin{array}{c}1.19^{* * * *} \\
(0.32)\end{array}$ & $\begin{array}{c}0.19_{\star \star \star \star}^{* * *} \\
(0.06)\end{array}$ & 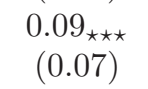 & $\begin{array}{c}0.25_{\star \star *}^{* * *} \\
(0.08)\end{array}$ & 0.37 & $\begin{array}{c}151 \\
{[0.00]}\end{array}$ \\
\hline Portugal & 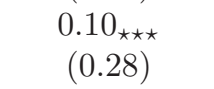 & $\begin{array}{c}0.50 \\
(0.42)\end{array}$ & $\begin{array}{c}1.02 \\
(0.66)\end{array}$ & $\begin{array}{c}0.27 \\
(0.47)\end{array}$ & 0.39 & $\begin{array}{c}160 \\
{[0.00]}\end{array}$ \\
\hline Spain & $\begin{array}{c}0.76^{* * *} \\
(0.21)\end{array}$ & $\begin{array}{c}0.80 \\
(0.58)\end{array}$ & $\begin{array}{c}0.29 \\
(0.59)\end{array}$ & $\begin{array}{c}0.01 \\
(0.89)\end{array}$ & 0.26 & $\begin{array}{c}139 \\
{[0.00]}\end{array}$ \\
\hline Sweden & $\begin{array}{c}1.39^{* * * *} \\
(0.29)\end{array}$ & $\begin{array}{l}0.30_{\star \star} \\
(0.35)\end{array}$ & $\begin{array}{l}0.28_{\star \star \star} \\
(0.29)\end{array}$ & $\begin{array}{c}0.48 \\
(1.13)\end{array}$ & 0.08 & $\begin{array}{c}193 \\
{[0.00]}\end{array}$ \\
\hline UK & $\begin{array}{c}1.05^{* * *} \\
(0.08)\end{array}$ & $\begin{array}{c}0.53_{\star \star \star *}^{* * *} \\
(0.17)\end{array}$ & $\begin{array}{c}0.77^{* * *} \\
(0.19)\end{array}$ & $\begin{array}{l}0.18_{\star \star} \\
(0.31)\end{array}$ & 0.36 & $\begin{array}{c}211 \\
{[0.00]}\end{array}$ \\
\hline
\end{tabular}

Notes: This table reports the long-run (LR), short-run linear (SR linear), and short-run Markov-switching (SR MS) elasticity of the PIT revenue with respect to its base, along with the Markov-switching model $R^{2}$ and the likelihood ratio (LR) test statistic described in Section 2.1. The stardard errors of coefficients and the LR test $p$-value are also reported. The symbols ${ }^{*},{ }^{* *}$, and ${ }^{* * *}$ indicate rejection of the null hypothesis that the elasticity is zero at the $90 \%, 95 \%$, and $99 \%$ confidence level, while the symbols $*$, ${ }_{\star \star}$, and ${ }_{\star \star \star}$ indicate rejection of the null hypothesis that the elasticity is one at the $90 \%, 95 \%$, and $99 \%$ confidence level. 
Table 2: Elasticity of PIT base with respect to GDP

\begin{tabular}{|c|c|c|c|c|c|c|}
\hline \multirow[t]{2}{*}{ Country } & \multirow[t]{2}{*}{$\begin{array}{l}\text { LR elasticity } \\
\delta^{T B} \\
\text { (s.e.) }\end{array}$} & \multirow[t]{2}{*}{$\begin{array}{c}\text { SR linear elasticity } \\
\beta^{T B} \\
\text { (s.e.) }\end{array}$} & \multicolumn{2}{|c|}{$\begin{array}{l}\text { SR MS elasticity } \\
\beta^{T B} \\
\text { (s.e.) }\end{array}$} & \multirow[t]{2}{*}{$\begin{array}{c}\text { MS model } \\
R^{2}\end{array}$} & \multirow[t]{2}{*}{$\begin{array}{c}\text { Likelihood ratic } \\
\text { test statistic } \\
\text { [p-value] }\end{array}$} \\
\hline & & & Boom & Recession & & \\
\hline Austria & $\begin{array}{c}1.37_{\star \star \star *}^{* * *} \\
(0.12)\end{array}$ & $\begin{array}{l}0.55_{\star \star *}^{* *} \\
(0.20)\end{array}$ & $\begin{array}{c}0.58_{\star \star}^{* * *} \\
(0.19)\end{array}$ & $\begin{array}{c}0.46_{\star} \\
(0.30)\end{array}$ & 0.24 & $\begin{array}{c}235 \\
{[0.00]}\end{array}$ \\
\hline Belgium & - & - & - & - & - & - \\
\hline Denmark & $\begin{array}{c}0.86_{\star}^{* * *} \\
(0.08)\end{array}$ & $\begin{array}{c}0.56_{\star \star}^{* * *} \\
(0.17)\end{array}$ & $\begin{array}{c}0.73^{* * *} \\
(0.22)\end{array}$ & $\begin{array}{l}0.54_{\star}^{* *} \\
(0.24)\end{array}$ & 0.53 & $\begin{array}{c}220 \\
{[0.00]}\end{array}$ \\
\hline Finland & $\begin{array}{c}0.61_{\star \star \star *}^{* * *} \\
(0.06)\end{array}$ & $\begin{array}{c}0.32_{\star \star \star \star}^{* *} \\
(0.12)\end{array}$ & $\begin{array}{c}0.35_{\text {*** }}^{* *} \\
(0.15)\end{array}$ & $\begin{array}{c}0.30_{\star \star \star \star}^{* *} \\
(0.13)\end{array}$ & 0.48 & $\begin{array}{c}211 \\
{[0.00]}\end{array}$ \\
\hline France & $\begin{array}{c}0.94^{* * *} \\
(0.06)\end{array}$ & $\begin{array}{c}0.71_{\star \star * \star}^{* * *} \\
(0.08)\end{array}$ & $\begin{array}{c}0.59_{\star \star \star \star}^{* * *} \\
(0.06)\end{array}$ & $\begin{array}{c}0.96^{* * *} \\
(0.22)\end{array}$ & 0.44 & $\begin{array}{c}696 \\
{[0.00]}\end{array}$ \\
\hline Germany & $\begin{array}{c}1.02^{* * *} \\
(0.23)\end{array}$ & $\begin{array}{c}0.46_{\star \star \star *}^{* * *} \\
(0.11)\end{array}$ & $\begin{array}{c}0.49_{\star \star * \star}^{* * *} \\
(0.13)\end{array}$ & $\begin{array}{c}0.40_{\star \star \star *}^{* * *} \\
(0.12)\end{array}$ & 0.32 & $\begin{array}{c}234 \\
{[0.00]}\end{array}$ \\
\hline Greece & $\begin{array}{c}1.11^{* * *} \\
(0.10)\end{array}$ & $\begin{array}{c}0.07_{\star \star \star \star} \\
(0.08)\end{array}$ & $\begin{array}{c}0.12_{\text {}} \\
(0.10)\end{array}$ & $\begin{array}{c}-0.03_{\star \star \star} \\
(0.08)\end{array}$ & 0.50 & $\begin{array}{c}140 \\
{[0.00]}\end{array}$ \\
\hline Ireland & $\begin{array}{c}1.51_{\star \star \star *}^{* * *} \\
(0.06)\end{array}$ & $\begin{array}{c}0.33_{\star \star \star \star}^{*} \\
(0.18)\end{array}$ & $\begin{array}{c}0.39_{\text {*ᄎ* }}^{* *} \\
(0.17)\end{array}$ & $\begin{array}{c}0.18_{\star \star \star} \\
(0.25)\end{array}$ & 0.34 & $\begin{array}{c}156 \\
{[0.00]}\end{array}$ \\
\hline Italy & $\begin{array}{c}1.27_{\star \star * \star}^{* * *} \\
(0.07)\end{array}$ & $\begin{array}{c}0.91^{* * *} \\
(0.16)\end{array}$ & $\begin{array}{c}1.05^{* * *} \\
(0.21)\end{array}$ & $\begin{array}{c}0.84^{* * *} \\
(0.24)\end{array}$ & 0.62 & $\begin{array}{c}210 \\
{[0.00]}\end{array}$ \\
\hline Netherlands & $\begin{array}{c}1.56_{\star \star \star \star}^{* * *} \\
(0.14)\end{array}$ & $\begin{array}{c}1.00^{* * *} \\
(0.22)\end{array}$ & $\begin{array}{c}1.00^{* * *} \\
(0.28)\end{array}$ & $\begin{array}{c}0.98^{* * * *} \\
(0.26)\end{array}$ & 0.57 & $\begin{array}{c}110 \\
{[0.00]}\end{array}$ \\
\hline Norway & $\begin{array}{c}-0.26_{\star \star \star \star} \\
(0.29)\end{array}$ & $\begin{array}{c}0.98 \\
(0.85)\end{array}$ & $\begin{array}{c}2.11^{* * *} \\
(0.73)\end{array}$ & $\begin{array}{l}-0.77 \\
(1.57)\end{array}$ & 0.32 & $\begin{array}{c}118 \\
{[0.00]}\end{array}$ \\
\hline Portugal & $\begin{array}{c}1.78_{\star * *}^{* * *} \\
(0.32)\end{array}$ & $\begin{array}{c}1.18^{* * *} \\
(0.22)\end{array}$ & $\begin{array}{c}1.93^{* * *} \\
(0.56)\end{array}$ & $\begin{array}{c}0.98^{* * *} \\
(0.22)\end{array}$ & 0.48 & $\begin{array}{c}200 \\
{[0.00]}\end{array}$ \\
\hline Spain & $\begin{array}{c}1.35_{\text {}}^{* * *} \\
(0.05)\end{array}$ & $\begin{array}{c}1.49_{\star \star *}^{* * *} \\
(0.12)\end{array}$ & $\begin{array}{c}1.13^{* * *} \\
(0.11)\end{array}$ & $\begin{array}{c}1.49_{\star \star *}^{* * *} \\
(0.15)\end{array}$ & 0.83 & $\begin{array}{c}231 \\
{[0.00]}\end{array}$ \\
\hline Sweden & $\begin{array}{c}0.81_{\star}^{* * *} \\
(0.11)\end{array}$ & $\begin{array}{c}0.54_{\star \star *}^{* * *} \\
(0.10)\end{array}$ & $\begin{array}{c}0.39_{\star \star * *}^{* * *} \\
(0.01)\end{array}$ & $\begin{array}{c}0.70_{\star \star}^{* * *} \\
(0.13)\end{array}$ & 0.46 & $\begin{array}{c}252 \\
{[0.00]}\end{array}$ \\
\hline UK & $\begin{array}{c}1.14_{\star \star}^{* * *} \\
(0.06)\end{array}$ & $\begin{array}{c}1.32_{\star}^{* * *} \\
(0.17)\end{array}$ & $\begin{array}{c}0.88^{* * *} \\
(0.15)\end{array}$ & $\begin{array}{c}1.92_{\star \star *}^{* * *} \\
(0.33)\end{array}$ & 0.70 & $\begin{array}{c}232 \\
{[0.00]}\end{array}$ \\
\hline
\end{tabular}

Notes: This table reports the long-run (LR), short-run linear (SR linear), and short-run Markov-switching (SR MS) elasticity of the PIT base with respect to GDP, along with the Markov-switching model $R^{2}$ and the likelihood ratio (LR) test statistic described in Section 2.1. The stardard errors of coefficients and the LR test $p$-value are also reported. The symbols ${ }^{*},{ }^{* *}$, and ${ }^{* * *}$ indicate rejection of the null hypothesis that the elasticity is zero at the $90 \%, 95 \%$, and $99 \%$ confidence level, while the symbols ${ }_{\star},{ }_{\star \star}$, and ${ }_{\star \star \star}$ indicate rejection of the null hypothesis that the elasticity is one at the $90 \%, 95 \%$, and $99 \%$ confidence level. 
Table 3: Elasticity of PIT revenue with respect to GDP

\begin{tabular}{lcccc}
\hline Country & $\begin{array}{c}\text { LR elasticity } \\
\delta^{T B} \cdot \delta^{B Y}\end{array}$ & $\begin{array}{c}\text { SR linear elasticity } \\
\beta^{T B} \cdot \beta^{B Y}\end{array}$ & $\begin{array}{c}\text { SR MS elasticity } \\
\beta^{T B} \cdot \beta^{B Y}\end{array}$ \\
\hline Austria & & & Boom & Recession \\
Belgium & 0.54 & 0.25 & -0.02 & 1.54 \\
Denmark & - & - & - & - \\
Finland & 0.26 & 0.38 & 0.39 & 0.43 \\
France & 0.84 & 0.16 & 0.14 & 0.27 \\
Germany & 1.90 & 0.33 & 0.14 & 1.08 \\
Greece & 3.06 & 0.42 & 0.45 & 0.32 \\
Ireland & 0.60 & 0.01 & -0.00 & -0.01 \\
Italy & 1.03 & 0.10 & 0.21 & 0.04 \\
Netherlands & 0.40 & 0.36 & 0.47 & 0.23 \\
Norway & 2.05 & 1.06 & 0.40 & 1.26 \\
Portugal & -0.31 & 0.18 & 0.20 & -0.19 \\
Spain & 0.17 & 0.59 & 1.96 & 0.26 \\
Sweden & 1.03 & 1.19 & 0.33 & 0.02 \\
UK & 1.13 & 0.16 & 0.11 & 0.34 \\
\hline
\end{tabular}

Notes: This table reports the product of the PIT tax-to-base and base-to-GDP elasticities combined in a single tax-to-GDP elasticity for the long-run (LR), short-run linear (SR), and short-run Markov-switching (SR MS). 
Table 4: Elasticity of CIT revenue with respect to its base

\begin{tabular}{|c|c|c|c|c|c|c|}
\hline \multirow[t]{2}{*}{ Country } & \multirow[t]{2}{*}{$\begin{array}{l}\text { LR elasticity } \\
\delta^{T B} \\
\text { (s.e.) }\end{array}$} & \multirow[t]{2}{*}{$\begin{array}{c}\text { SR linear elasticity } \\
\beta^{T B} \\
\text { (s.e.) } \\
\end{array}$} & \multicolumn{2}{|c|}{$\begin{array}{l}\text { SR MS elasticity } \\
\beta^{T B} \\
\text { (s.e.) }\end{array}$} & \multirow[t]{2}{*}{$\begin{array}{c}\text { MS model } \\
R^{2}\end{array}$} & \multirow[t]{2}{*}{$\begin{array}{c}\text { Likelihood ratio } \\
\text { test statistic } \\
\text { [p-value] }\end{array}$} \\
\hline & & & Boom & Recession & & \\
\hline Austria & - & - & - & - & - & - \\
\hline Belgium & - & - & - & - & - & - \\
\hline Denmark & - & - & - & - & - & - \\
\hline Finland & $\begin{array}{c}1.18^{* * *} \\
(0.25)\end{array}$ & $\begin{array}{c}0.25 \\
(0.45)\end{array}$ & 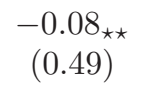 & $\begin{array}{l}1.05 \\
(0.85)\end{array}$ & 0.52 & $\begin{array}{c}82 \\
{[0.00]}\end{array}$ \\
\hline France & $\begin{array}{l}0.46_{\star \star}^{*} \\
(0.27)\end{array}$ & $\begin{array}{c}3.73_{\star \star \star \star *}^{* * *} \\
(0.60)\end{array}$ & $\begin{array}{c}0.60 \\
(0.47)\end{array}$ & $\begin{array}{c}9.99_{\star \star \star}^{* * *} \\
(1.68)\end{array}$ & 0.67 & $\begin{array}{c}208 \\
{[0.00]}\end{array}$ \\
\hline Germany & $\begin{array}{c}1.54^{* * *} \\
(0.42)\end{array}$ & $\begin{array}{c}0.15 \\
(0.73)\end{array}$ & $\begin{array}{c}0.39 \\
(0.82)\end{array}$ & $\begin{array}{c}0.78 \\
(1.04)\end{array}$ & 0.20 & $\begin{array}{c}100 \\
{[0.00]}\end{array}$ \\
\hline Greece & 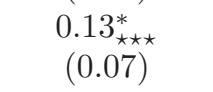 & $\begin{array}{c}-0.00_{\star \star \star \star} \\
(0.10)\end{array}$ & $\begin{array}{c}0.00_{\star \star \star} \\
(0.10)\end{array}$ & $\begin{array}{c}0.00_{\star \star \star} \\
(0.20)\end{array}$ & 0.10 & $\begin{array}{c}170 \\
{[0.00]}\end{array}$ \\
\hline Ireland & $\begin{array}{c}0.86^{* * *} \\
(0.21)\end{array}$ & 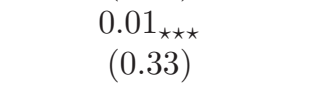 & 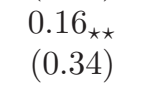 & 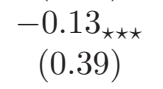 & 0.17 & $\begin{array}{c}88 \\
{[0.00]}\end{array}$ \\
\hline Italy & $\begin{array}{c}1.26_{\star}^{* * *} \\
(0.14)\end{array}$ & $\begin{array}{c}-0.21_{\text {ᄎ* }} \\
(0.51)\end{array}$ & 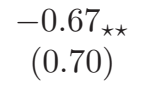 & $\begin{array}{c}0.12_{\star} \\
(0.50)\end{array}$ & 0.34 & $\begin{array}{c}114 \\
{[0.00]}\end{array}$ \\
\hline Netherlands & - & - & - & - & - & - \\
\hline Norway & - & - & - & - & - & - \\
\hline Portugal & $\begin{array}{c}1.16^{* * *} \\
(0.10)\end{array}$ & $\begin{array}{c}0.21_{\star \star \star \star} \\
(0.16)\end{array}$ & $\begin{array}{c}0.29 \\
(0.51)\end{array}$ & $\begin{array}{c}0.19_{\star \star \star} \\
(0.16)\end{array}$ & 0.23 & $\begin{array}{c}134 \\
{[0.00]}\end{array}$ \\
\hline Spain & $\begin{array}{c}3.21_{\star \star *}^{* * *} \\
(0.61)\end{array}$ & $\begin{array}{c}1.21 \\
(2.25)\end{array}$ & $\begin{array}{c}2.21 \\
(2.87)\end{array}$ & $\begin{array}{l}-0.06 \\
(2.98)\end{array}$ & 0.35 & $\begin{array}{c}28 \\
{[0.01]}\end{array}$ \\
\hline Sweden & $\begin{array}{c}1.11^{* * *} \\
(0.25)\end{array}$ & $\begin{array}{c}-0.11_{\star \star \star} \\
(0.19)\end{array}$ & 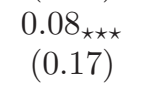 & $\begin{array}{c}-1.50_{\star \star \star \star}^{* *} \\
(0.58)\end{array}$ & 0.50 & $\begin{array}{c}117 \\
{[0.00]}\end{array}$ \\
\hline UK & $\begin{array}{c}0.63_{\star \star * *}^{* * *} \\
(0.09)\end{array}$ & $\begin{array}{l}0.43_{\star} \\
(0.30)\end{array}$ & $\begin{array}{l}0.19_{\star} \\
(0.43)\end{array}$ & $\begin{array}{l}0.61^{* *} \\
(0.27)\end{array}$ & 0.39 & $\begin{array}{c}128 \\
{[0.00]}\end{array}$ \\
\hline
\end{tabular}

Notes: This table reports the long-run (LR), short-run linear (SR linear), and short-run Markov-switching (SR MS) elasticity of the CIT revenue with respect to its base, along with the Markov-switching model $R^{2}$ and the likelihood ratio (LR) test statistic described in Section 2.1. The stardard errors of coefficients and the LR test $p$-value are also reported. The symbols ${ }^{*},{ }^{* *}$, and ${ }^{* * *}$ indicate rejection of the null hypothesis that the elasticity is zero at the $90 \%, 95 \%$, and $99 \%$ confidence level, while the symbols $*$, ${ }_{\star \star}$, and ${ }_{\star \star \star}$ indicate rejection of the null hypothesis that the elasticity is one at the $90 \%, 95 \%$, and $99 \%$ confidence level. 
Table 5: Elasticity of CIT base with respect to GDP

\begin{tabular}{|c|c|c|c|c|c|c|}
\hline \multirow[t]{2}{*}{ Country } & \multirow[t]{2}{*}{$\begin{array}{l}\text { LR elasticity } \\
\delta^{T B} \\
\text { (s.e.) }\end{array}$} & \multirow[t]{2}{*}{$\begin{array}{c}\text { SR linear elasticity } \\
\beta^{T B} \\
\text { (s.e.) }\end{array}$} & \multicolumn{2}{|c|}{$\begin{array}{l}\text { SR MS elasticity } \\
\beta^{T B} \\
\text { (s.e.) }\end{array}$} & \multirow[t]{2}{*}{$\begin{array}{c}\text { MS model } \\
R^{2}\end{array}$} & \multirow[t]{2}{*}{$\begin{array}{c}\text { Likelihood ratio } \\
\text { test statistic } \\
\text { [p-value }]\end{array}$} \\
\hline & & & Boom & Recession & & \\
\hline Austria & $\begin{array}{c}2.29_{\text {*** }}^{* * *} \\
(0.17)\end{array}$ & $\begin{array}{c}3.52_{\star \star \star *}^{* * *} \\
(0.49)\end{array}$ & $\begin{array}{c}3.70_{\star \star * \star}^{* * *} \\
(0.46)\end{array}$ & $\begin{array}{c}3.44_{\star \star \star}^{* * *} \\
(0.53)\end{array}$ & 0.59 & $\begin{array}{c}197 \\
{[0.00]}\end{array}$ \\
\hline Belgium & - & - & - & - & - & - \\
\hline Denmark & - & - & - & - & - & - \\
\hline Finland & $\begin{array}{c}2.57_{\star \star * *}^{* * *} \\
(0.23)\end{array}$ & $\begin{array}{c}3.12_{\star \star * \star}^{* * *} \\
(0.46)\end{array}$ & $\begin{array}{c}3.00_{\star \star * *}^{* * *} \\
(0.52)\end{array}$ & $\begin{array}{c}3.34_{\star \star * *}^{* * *} \\
(0.60)\end{array}$ & 0.56 & $\begin{array}{c}163 \\
{[0.00]}\end{array}$ \\
\hline France & $\begin{array}{c}3.00_{\star \star * *}^{* * *} \\
(0.32)\end{array}$ & $\begin{array}{c}2.55_{\text {*** }}^{* * *} \\
(0.32)\end{array}$ & $\begin{array}{c}2.07_{\text {**** }}^{* * *} \\
(0.22)\end{array}$ & $\begin{array}{c}4.30_{\star \star * \star *}^{* * *} \\
(1.24)\end{array}$ & 0.46 & $\begin{array}{c}510 \\
{[0.00]}\end{array}$ \\
\hline Germany & $\begin{array}{c}3.01_{\star \star \star *}^{* * *} \\
(0.71)\end{array}$ & $\begin{array}{c}2.19_{\star \star * *}^{* * *} \\
(0.33)\end{array}$ & $\begin{array}{c}1.88_{\star \star}^{* * *} \\
(0.37)\end{array}$ & $\begin{array}{c}2.38_{\text {*** }}^{* * *} \\
(0.34)\end{array}$ & 0.54 & $\begin{array}{c}202 \\
{[0.00]}\end{array}$ \\
\hline Greece & $\begin{array}{c}1.12^{* * *} \\
(0.19)\end{array}$ & $\begin{array}{c}-0.02_{\star \star \star \star} \\
(0.10)\end{array}$ & 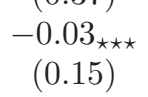 & 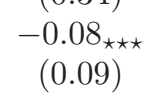 & 0.23 & $\begin{array}{c}150 \\
{[0.00]}\end{array}$ \\
\hline Ireland & $\begin{array}{c}1.89_{\star \star * \star}^{* * *} \\
(0.24)\end{array}$ & $\begin{array}{c}2.00_{\star \star \star *}^{* * *} \\
(0.34)\end{array}$ & $\begin{array}{l}1.97_{* \star *}^{* * *} \\
(0.32)\end{array}$ & $\begin{array}{c}2.08_{* *}^{* * *} \\
(0.50)\end{array}$ & 0.56 & $\begin{array}{c}131 \\
{[0.00]}\end{array}$ \\
\hline Italy & $\begin{array}{c}3.45_{\text {*** }}^{* * *} \\
(0.26)\end{array}$ & $\begin{array}{c}2.90_{\star \star * *}^{* * *} \\
(0.35)\end{array}$ & $\begin{array}{c}2.40_{\star \star * *}^{* * *} \\
(0.42)\end{array}$ & $\begin{array}{c}3.73_{\star \star \star *}^{* * *} \\
(0.68)\end{array}$ & 0.65 & $\begin{array}{c}203 \\
{[0.00]}\end{array}$ \\
\hline Netherlands & - & - & - & - & - & - \\
\hline Norway & - & - & - & - & - & - \\
\hline Portugal & $\begin{array}{c}3.44_{\star \star}^{* * *} \\
(1.18)\end{array}$ & $\begin{array}{l}2.28^{* *} \\
(1.00)\end{array}$ & $\begin{array}{c}2.13 \\
(1.48)\end{array}$ & $\begin{array}{l}2.33^{* *} \\
(1.14)\end{array}$ & 0.16 & $\begin{array}{c}145 \\
{[0.00]}\end{array}$ \\
\hline Spain & $\begin{array}{c}1.66^{* * *} \\
(0.39)\end{array}$ & $\begin{array}{c}3.02_{\star \star *}^{* * *} \\
(0.86)\end{array}$ & $\begin{array}{c}2.27_{\star}^{* * *} \\
(0.68)\end{array}$ & $\begin{array}{c}5.32_{\star \star * \star}^{* * *} \\
(1.22)\end{array}$ & 0.34 & $\begin{array}{c}143 \\
{[0.00]}\end{array}$ \\
\hline Sweden & $\begin{array}{c}3.80_{\star \star *}^{* * *} \\
(0.49)\end{array}$ & $\begin{array}{c}3.66_{\text {*** }}^{* * *} \\
(0.95)\end{array}$ & $\begin{array}{c}3.37_{\star \star * *}^{* * *} \\
(0.78)\end{array}$ & $\begin{array}{c}4.44_{\star \star \star *}^{* * *} \\
(0.95)\end{array}$ & 0.40 & $\begin{array}{c}148 \\
{[0.00]}\end{array}$ \\
\hline UK & $\begin{array}{c}3.99_{\text {*** }}^{* * *} \\
(0.33)\end{array}$ & $\begin{array}{c}3.61_{\star \star * *}^{* * *} \\
(0.48)\end{array}$ & $\begin{array}{c}2.62_{\star \star * *}^{* * *} \\
(0.43)\end{array}$ & $\begin{array}{c}3.73_{\star \star * \star}^{* * *} \\
(0.86)\end{array}$ & 0.68 & $\begin{array}{c}183 \\
{[0.00]}\end{array}$ \\
\hline
\end{tabular}

Notes: This table reports the long-run (LR), short-run linear (SR linear), and short-run Markov-switching (SR MS) elasticity of the CIT base with respect to GDP, along with the Markov-switching model $R^{2}$ and the likelihood ratio (LR) test statistic described in Section 2.1. The stardard errors of coefficients and the LR test $p$-value are also reported. The symbols ${ }^{*},{ }^{* *}$, and ${ }^{* * *}$ indicate rejection of the null hypothesis that the elasticity is zero at the $90 \%, 95 \%$, and $99 \%$ confidence level, while the symbols ${ }_{\star},{ }_{\star \star}$, and ${ }_{\star \star \star}$ indicate rejection of the null hypothesis that the elasticity is one at the $90 \%, 95 \%$, and $99 \%$ confidence level. 
Table 6: Elasticity of CIT revenue with respect to GDP

\begin{tabular}{lcccc}
\hline Country & $\begin{array}{c}\text { LR elasticity } \\
\delta^{T B} \cdot \delta^{B Y}\end{array}$ & $\begin{array}{c}\text { SR linear elasticity } \\
\beta^{T B} \cdot \beta^{B Y}\end{array}$ & \multicolumn{2}{c}{$\begin{array}{c}\text { SR } \\
\beta^{T B} \cdot \beta^{B Y}\end{array}$} \\
\hline & & & Boom & Recession \\
\hline Austria & - & - & - & - \\
Belgium & - & - & - & - \\
Denmark & - & - & - & - \\
Finland & 3.03 & 0.79 & -0.23 & 3.51 \\
France & 1.39 & 9.53 & 1.24 & 43.00 \\
Germany & 4.63 & 0.32 & 0.73 & 1.85 \\
Greece & 0.14 & 0.00 & 0.00 & 0.00 \\
Ireland & 1.62 & 0.01 & 0.32 & -0.27 \\
Italy & 4.36 & -0.60 & -1.61 & 0.43 \\
Netherlands & - & - & - & - \\
Norway & - & - & - & - \\
Portugal & 3.99 & 0.47 & 0.62 & 0.45 \\
Spain & 5.33 & 3.67 & 5.00 & -0.31 \\
Sweden & 4.22 & -0.39 & 0.27 & -6.68 \\
UK & 2.50 & 1.56 & 0.50 & 2.26 \\
\hline
\end{tabular}

Notes: This table reports the product of the CIT tax-to-base and base-to-GDP elasticities combined in a single tax-to-GDP elasticity for the long-run (LR), short-run linear (SR), and short-run Markov-switching (SR MS). 
Table 7: Elasticity of IND revenue with respect to its base

\begin{tabular}{|c|c|c|c|c|c|c|}
\hline \multirow[t]{2}{*}{ Country } & \multirow[t]{2}{*}{$\begin{array}{l}\text { LR elasticity } \\
\delta^{T B} \\
\text { (s.e.) }\end{array}$} & \multirow[t]{2}{*}{$\begin{array}{c}\text { SR linear elasticity } \\
\beta^{T B} \\
\text { (s.e.) }\end{array}$} & \multicolumn{2}{|c|}{$\begin{array}{l}\text { SR MS elasticity } \\
\beta^{T B} \\
\text { (s.e.) }\end{array}$} & \multirow[t]{2}{*}{$\begin{array}{c}\text { MS model } \\
R^{2}\end{array}$} & \multirow[t]{2}{*}{$\begin{array}{c}\text { Likelihood ratio } \\
\text { test statistic } \\
\text { [p-value }]\end{array}$} \\
\hline & & & Boom & Recession & & \\
\hline Austria & $\begin{array}{l}0.96^{* *} \\
(0.42)\end{array}$ & $\begin{array}{c}1.47 \\
(1.49)\end{array}$ & $\begin{array}{l}1.56^{* *} \\
(0.62)\end{array}$ & $\begin{array}{c}0.00 \\
(1.86)\end{array}$ & 0.33 & $\begin{array}{c}319 \\
{[0.00]}\end{array}$ \\
\hline Belgium & 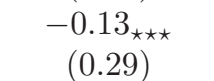 & $\begin{array}{l}0.96^{* *} \\
(0.43)\end{array}$ & $\begin{array}{c}0.85^{* * *} \\
(0.26)\end{array}$ & $\begin{array}{l}1.37^{*} \\
(0.76)\end{array}$ & 0.29 & $\begin{array}{c}258 \\
{[0.00]}\end{array}$ \\
\hline Denmark & $\begin{array}{c}1.75_{\star \star * \star}^{* * *} \\
(0.25)\end{array}$ & $\begin{array}{c}0.78^{* * *} \\
(0.16)\end{array}$ & $\begin{array}{c}0.72^{* * *} \\
(0.26)\end{array}$ & $\begin{array}{c}0.80^{* * *} \\
(0.19)\end{array}$ & 0.25 & $\begin{array}{c}332 \\
{[0.00]}\end{array}$ \\
\hline Finland & $\begin{array}{c}1.34_{\star}^{* * *} \\
(0.19)\end{array}$ & $\begin{array}{c}0.81^{* * *} \\
(0.24)\end{array}$ & $\begin{array}{c}0.59_{\star}^{* * *} \\
(0.22)\end{array}$ & $\begin{array}{l}1.60^{* *} \\
(0.62)\end{array}$ & 0.29 & $\begin{array}{c}311 \\
{[0.00]}\end{array}$ \\
\hline France & $\begin{array}{l}0.31_{\star \star} \\
(0.28)\end{array}$ & $\begin{array}{c}0.40_{\star \star \star \star \star}^{*} \\
(0.22)\end{array}$ & $\begin{array}{c}0.31_{\star \star \star \star}^{*} \\
(0.18)\end{array}$ & $\begin{array}{c}0.82 \\
(0.82)\end{array}$ & 0.15 & $\begin{array}{c}372 \\
{[0.00]}\end{array}$ \\
\hline Germany & $\begin{array}{c}-0.50_{\star \star \star \star} \\
(0.44)\end{array}$ & $\begin{array}{l}0.88^{*} \\
(0.45)\end{array}$ & $\begin{array}{l}0.89^{* *} \\
(0.42)\end{array}$ & $\begin{array}{c}0.57 \\
(1.97)\end{array}$ & 0.18 & $\begin{array}{c}281 \\
{[0.00]}\end{array}$ \\
\hline Greece & $\begin{array}{c}0.97^{* * *} \\
(0.08)\end{array}$ & 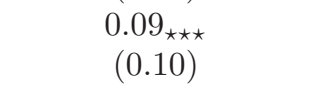 & 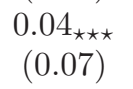 & 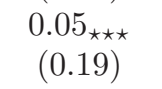 & 0.16 & $\begin{array}{c}157 \\
{[0.00]}\end{array}$ \\
\hline Ireland & $\begin{array}{c}1.84_{\star \star \star *}^{* * *} \\
(0.10)\end{array}$ & $\begin{array}{c}1.07^{* * *} \\
(0.23)\end{array}$ & $\begin{array}{l}0.70^{* *} \\
(0.34)\end{array}$ & $\begin{array}{c}1.10^{* * *} \\
(0.24)\end{array}$ & 0.38 & $\begin{array}{c}183 \\
{[0.00]}\end{array}$ \\
\hline Italy & $\begin{array}{c}2.75_{\text {}}^{* * * *} \\
(0.33)\end{array}$ & $\begin{array}{c}0.55 \\
(0.47)\end{array}$ & $\begin{array}{c}0.39 \\
(0.44)\end{array}$ & $\begin{array}{c}1.69 \\
(1.77)\end{array}$ & 0.08 & $\begin{array}{c}299 \\
{[0.00]}\end{array}$ \\
\hline Netherlands & $\begin{array}{c}1.38_{\star \star \star *}^{* * *} \\
(0.13)\end{array}$ & $\begin{array}{c}0.06 \\
(0.72)\end{array}$ & $\begin{array}{c}-0.10_{\star} \\
(0.64)\end{array}$ & $\begin{array}{c}0.17 \\
(2.15)\end{array}$ & 0.48 & $\begin{array}{c}248 \\
{[0.00]}\end{array}$ \\
\hline Norway & - & - & - & - & - & - \\
\hline Portugal & $\begin{array}{c}1.43_{\star \star}^{* * *} \\
(0.21)\end{array}$ & $\begin{array}{c}1.90^{* * *} \\
(0.62)\end{array}$ & $\begin{array}{l}1.63^{* *} \\
(0.63)\end{array}$ & $\begin{array}{c}2.38^{* * *} \\
(0.85)\end{array}$ & 0.41 & $\begin{array}{c}189 \\
{[0.00]}\end{array}$ \\
\hline Spain & $\begin{array}{c}1.30^{* * *} \\
(0.26)\end{array}$ & $\begin{array}{c}2.18^{* * *} \\
(0.78)\end{array}$ & $\begin{array}{c}1.98^{* * *} \\
(0.60)\end{array}$ & $\begin{array}{l}3.29^{* *} \\
(1.55)\end{array}$ & 0.33 & $\begin{array}{c}127 \\
{[0.00]}\end{array}$ \\
\hline Sweden & $\begin{array}{c}6.36_{\star \star \star \star *}^{* * *} \\
(1.70)\end{array}$ & $\begin{array}{c}0.55 \\
(1.34)\end{array}$ & $\begin{array}{c}0.46 \\
(1.07)\end{array}$ & $\begin{array}{c}1.27 \\
(3.32)\end{array}$ & 0.06 & $\begin{array}{c}184 \\
{[0.00]}\end{array}$ \\
\hline UK & $\begin{array}{c}0.82_{\text {*** }}^{* * *} \\
(0.07)\end{array}$ & $\begin{array}{l}0.70^{*} \\
(0.38)\end{array}$ & 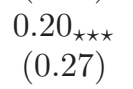 & $\begin{array}{l}1.58 \\
(1.21)\end{array}$ & 0.33 & $\begin{array}{c}306 \\
{[0.00]}\end{array}$ \\
\hline
\end{tabular}

Notes: This table reports the long-run (LR), short-run linear (SR linear), and short-run Markov-switching (SR MS) elasticity of the Indirect tax revenue with respect to its base, along with the Markov-switching model $R^{2}$ and the likelihood ratio (LR) test statistic described in Section 2.1. The stardard errors of coefficients and the LR test $p$-value are also reported. The symbols ${ }^{*},{ }^{* *}$, and ${ }^{* * *}$ indicate rejection of the null hypothesis that the elasticity is zero at the $90 \%, 95 \%$, and $99 \%$ confidence level, while the symbols

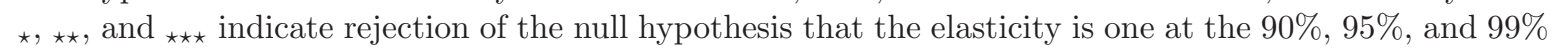
confidence level. 
Table 8: Elasticity of IND base with respect to GDP

\begin{tabular}{|c|c|c|c|c|c|c|}
\hline \multirow[t]{2}{*}{ Country } & \multirow[t]{2}{*}{$\begin{array}{l}\text { LR elasticity } \\
\delta^{T B} \\
\quad \text { (s.e.) }\end{array}$} & \multirow[t]{2}{*}{$\begin{array}{c}\text { SR linear elasticity } \\
\beta^{T B} \\
\text { (s.e.) }\end{array}$} & \multicolumn{2}{|c|}{$\begin{array}{l}\text { SR MS elasticity } \\
\beta^{T B} \\
\text { (s.e.) }\end{array}$} & \multirow[t]{2}{*}{$\begin{array}{c}\text { MS model } \\
R^{2}\end{array}$} & \multirow[t]{2}{*}{$\begin{array}{c}\text { Likelihood ratio } \\
\text { test statistic } \\
\text { [p-value] }\end{array}$} \\
\hline & & & Boom & Recession & & \\
\hline Austria & $\begin{array}{c}0.31_{\text {*大* }}^{* * *} \\
(0.04)\end{array}$ & $\begin{array}{c}0.08_{\star \star \star \star *}^{* * *} \\
(0.02)\end{array}$ & $\begin{array}{c}0.11_{\text {**** }}^{* * *} \\
(0.02)\end{array}$ & 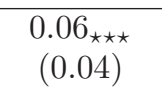 & 0.24 & $\begin{array}{c}508 \\
{[0.00]}\end{array}$ \\
\hline Belgium & $\begin{array}{c}0.37_{\star \star \star \star}^{* * *} \\
(0.10)\end{array}$ & $\begin{array}{c}0.59_{\star \star \star \star}^{* * *} \\
(0.08)\end{array}$ & $\begin{array}{c}0.47_{\text {*** }}^{* * *} \\
(0.05)\end{array}$ & $\begin{array}{c}0.69_{\star \star}^{* * *} \\
(0.13)\end{array}$ & 0.52 & $\begin{array}{c}359 \\
{[0.00]}\end{array}$ \\
\hline Denmark & $\begin{array}{c}0.32_{\star \star \star \star}^{*} \\
(0.16)\end{array}$ & $\begin{array}{c}0.47_{\star \star * *}^{* * *} \\
(0.11)\end{array}$ & $\begin{array}{c}0.58_{\star \star * *}^{* * *} \\
(0.12)\end{array}$ & $\begin{array}{c}0.52_{\star \star * \star}^{* * *} \\
(0.16)\end{array}$ & 0.27 & $\begin{array}{c}336 \\
{[0.00]}\end{array}$ \\
\hline Finland & $\begin{array}{c}0.50_{\star \star \star *}^{* * *} \\
(0.07)\end{array}$ & $\begin{array}{c}0.44_{\star \star *}^{* * *} \\
(0.08)\end{array}$ & $\begin{array}{c}0.46_{\star \star * \star}^{* * *} \\
(0.08)\end{array}$ & $\begin{array}{c}0.34_{\star \star \star}^{* * *} \\
(0.12)\end{array}$ & 0.39 & $\begin{array}{c}397 \\
{[0.00]}\end{array}$ \\
\hline France & $\begin{array}{c}0.69_{\star \star *}^{* * *} \\
(0.08)\end{array}$ & $\begin{array}{c}0.58_{\star \star * \star}^{* * *} \\
(0.10)\end{array}$ & $\begin{array}{c}0.70_{\star \star * *}^{* * *} \\
(0.08)\end{array}$ & $\begin{array}{c}0.36_{\star \star \star \star}^{* *} \\
(0.18)\end{array}$ & 0.39 & $\begin{array}{c}447 \\
{[0.00]}\end{array}$ \\
\hline Germany & $\begin{array}{l}0.50_{\star * *}^{* *} \\
(0.21)\end{array}$ & $\begin{array}{c}0.29_{* \star *}^{* * *} \\
(0.10)\end{array}$ & $\begin{array}{c}0.44_{\star \star \star}^{* * *} \\
(0.10)\end{array}$ & 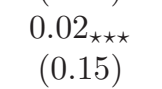 & 0.28 & $\begin{array}{c}401 \\
{[0.00]}\end{array}$ \\
\hline Greece & $\begin{array}{c}0.83_{\star \star \star *}^{* * *} \\
(0.05)\end{array}$ & $\begin{array}{c}-0.11_{\star \star \star \star} \\
(0.10)\end{array}$ & 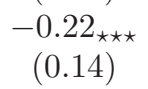 & $\begin{array}{c}-0.066_{\star \star \star} \\
(0.13)\end{array}$ & 0.32 & $\begin{array}{c}148 \\
{[0.00]}\end{array}$ \\
\hline Ireland & $\begin{array}{c}0.99^{* * *} \\
(0.07)\end{array}$ & $\begin{array}{c}0.31_{\star \star * *}^{* * *} \\
(0.11)\end{array}$ & $\begin{array}{c}0.22_{\star \star \star \star}^{*} \\
(0.13)\end{array}$ & $\begin{array}{c}0.34_{\star \star \star \star}^{* *} \\
(0.14)\end{array}$ & 0.24 & $\begin{array}{c}189 \\
{[0.00]}\end{array}$ \\
\hline Italy & $\begin{array}{c}0.79_{\star \star \star *}^{* * *} \\
(0.08)\end{array}$ & $\begin{array}{c}0.50_{\star \star * \star}^{* * *} \\
(0.09)\end{array}$ & $\begin{array}{c}0.62_{\star \star * \star}^{* * *} \\
(0.10)\end{array}$ & $\begin{array}{c}0.31_{\star \star \star \star}^{* *} \\
(0.13)\end{array}$ & 0.35 & $\begin{array}{c}433 \\
{[0.00]}\end{array}$ \\
\hline Netherlands & $\begin{array}{c}1.41_{\star \star * *}^{* * *} \\
(0.08)\end{array}$ & $\begin{array}{c}0.52_{\star \star * *}^{* * *} \\
(0.11)\end{array}$ & $\begin{array}{c}0.43_{\star \star * \star}^{* * *} \\
(0.10)\end{array}$ & $\begin{array}{c}0.58_{\star \star * \star}^{* * *} \\
(0.15)\end{array}$ & 0.25 & $\begin{array}{c}416 \\
{[0.00]}\end{array}$ \\
\hline Norway & $\begin{array}{c}-0.04_{\star \star \star \star} \\
(0.15)\end{array}$ & $\begin{array}{c}0.26_{\star \star \star \star *}^{* * *} \\
(0.09)\end{array}$ & $\begin{array}{c}0.20_{\star \star \star \star}^{*} \\
(0.11)\end{array}$ & $\begin{array}{c}0.28_{\star \star \star \star}^{* *} \\
(0.13)\end{array}$ & 0.08 & $\begin{array}{c}563 \\
{[0.00]}\end{array}$ \\
\hline Portugal & $\begin{array}{c}1.05^{* * *} \\
(0.08)\end{array}$ & $\begin{array}{c}0.85^{* * *} \\
(0.09)\end{array}$ & $\begin{array}{c}0.64_{\star \star \star}^{* * *} \\
(0.09)\end{array}$ & $\begin{array}{c}0.94^{* * *} \\
(0.14)\end{array}$ & 0.61 & $\begin{array}{c}319 \\
{[0.00]}\end{array}$ \\
\hline Spain & $\begin{array}{c}1.15_{\star \star \star *}^{* * *} \\
(0.02)\end{array}$ & $\begin{array}{c}1.04^{* * *} \\
(0.14)\end{array}$ & $\begin{array}{c}1.02^{* * *} \\
(0.14)\end{array}$ & $\begin{array}{c}0.86^{* * *} \\
(0.21)\end{array}$ & 0.70 & $\begin{array}{c}181 \\
{[0.00]}\end{array}$ \\
\hline Sweden & $\begin{array}{c}0.56_{\star \star \star \star}^{* * *} \\
(0.05)\end{array}$ & $\begin{array}{c}0.39_{\star \star \star *}^{* * *} \\
(0.08)\end{array}$ & $\begin{array}{c}0.41_{\text {*** }}^{* * *} \\
(0.07)\end{array}$ & $\begin{array}{c}0.38_{\star \star \star \star}^{* * *} \\
(0.13)\end{array}$ & 0.32 & $\begin{array}{c}380 \\
{[0.00]}\end{array}$ \\
\hline UK & $\begin{array}{c}1.19_{\star \star \star *}^{* * *} \\
(0.05)\end{array}$ & $\begin{array}{c}0.72_{\star \star * \star}^{* * *} \\
(0.09)\end{array}$ & $\begin{array}{c}0.56_{\star \star \star *}^{* * *} \\
(0.08)\end{array}$ & $\begin{array}{c}0.74_{\star}^{* * *} \\
(0.14)\end{array}$ & 0.47 & $\begin{array}{c}443 \\
{[0.00]}\end{array}$ \\
\hline
\end{tabular}

Notes: This table reports the long-run (LR), short-run linear (SR linear), and short-run Markov-switching (SR MS) elasticity of the Indirect tax base with respect to GDP, along with the Markov-switching model $R^{2}$ and the likelihood ratio (LR) test statistic described in Section 2.1. The stardard errors of coefficients and the LR test $p$-value are also reported. The symbols ${ }^{*},{ }^{* *}$, and ${ }^{* * *}$ indicate rejection of the null hypothesis that the elasticity is zero at the $90 \%, 95 \%$, and $99 \%$ confidence level, while the symbols $*$, ${ }_{\star \star}$, and ${ }_{\star \star \star}$ indicate rejection of the null hypothesis that the elasticity is one at the $90 \%, 95 \%$, and $99 \%$ confidence level. 
Table 9: Elasticity of IND revenue with respect to GDP

\begin{tabular}{lcccc}
\hline Country & $\begin{array}{c}\text { LR elasticity } \\
\delta^{T B} \cdot \delta^{B Y}\end{array}$ & $\begin{array}{c}\text { SR linear elasticity } \\
\beta^{T B} \cdot \beta^{B Y}\end{array}$ & $\begin{array}{c}\text { SR MS elasticity } \\
\beta^{T B} \cdot \beta^{B Y}\end{array}$ \\
\hline Austria & & & Boom & Recession \\
Belgium & -0.30 & 0.12 & 0.16 & 0.00 \\
Denmark & 0.56 & 0.56 & 0.40 & 0.94 \\
Finland & 0.67 & 0.37 & 0.42 & 0.42 \\
France & 0.21 & 0.35 & 0.27 & 0.55 \\
Germany & -0.25 & 0.23 & 0.22 & 0.29 \\
Greece & 0.80 & 0.25 & 0.39 & 0.01 \\
Ireland & 1.83 & -0.01 & -0.01 & -0.00 \\
Italy & 2.17 & 0.33 & 0.16 & 0.38 \\
Netherlands & 1.94 & 0.27 & 0.24 & 0.52 \\
Norway & - & 0.03 & -0.04 & 0.10 \\
Portugal & 1.51 & - & - & - \\
Spain & 1.50 & 1.61 & 1.04 & 2.23 \\
Sweden & 3.54 & 2.28 & 2.01 & 2.84 \\
UK & 0.98 & 0.21 & 0.19 & 0.48 \\
\hline
\end{tabular}

Notes: This table reports the product of the Indirect tax-to-base and base-to-GDP elasticities combined in a single tax-to-GDP elasticity for the long-run (LR), short-run linear (SR), and short-run Markovswitching (SR MS). 
Table 10: Elasticity of SC revenue with respect to its base

\begin{tabular}{|c|c|c|c|c|c|c|}
\hline \multirow[t]{2}{*}{ Country } & \multirow[t]{2}{*}{$\begin{array}{l}\text { LR elasticity } \\
\delta^{T B} \\
\text { (s.e.) } \\
\end{array}$} & \multirow[t]{2}{*}{$\begin{array}{c}\text { SR linear elasticity } \\
\beta^{T B} \\
\text { (s.e.) } \\
\end{array}$} & \multicolumn{2}{|c|}{$\begin{array}{c}\text { SR MS elasticity } \\
\beta^{T B} \\
\text { (s.e.) } \\
\end{array}$} & \multirow[t]{2}{*}{$\begin{array}{c}\text { MS model } \\
R^{2}\end{array}$} & \multirow[t]{2}{*}{$\begin{array}{c}\text { Likelihood ratio } \\
\text { test statistic } \\
\text { [p-value] }\end{array}$} \\
\hline & & & Boom & Recession & & \\
\hline Austria & $\begin{array}{c}0.81^{* * *} \\
(0.17)\end{array}$ & $\begin{array}{c}0.59^{*} \\
(0.32)\end{array}$ & $\begin{array}{l}0.51_{\text {** }}^{* *} \\
(0.22)\end{array}$ & $\begin{array}{l}0.91^{*} \\
(0.52)\end{array}$ & 0.37 & $\begin{array}{c}226 \\
{[0.00]}\end{array}$ \\
\hline Belgium & $\begin{array}{c}0.43_{\star \star \star *}^{* *} \\
(0.20)\end{array}$ & $\begin{array}{c}0.72^{* * *} \\
(0.25)\end{array}$ & $\begin{array}{c}0.83^{* * *} \\
(0.20)\end{array}$ & $\begin{array}{l}0.24_{\star} \\
(0.44)\end{array}$ & 0.27 & $\begin{array}{c}242 \\
{[0.00]}\end{array}$ \\
\hline Denmark & $\begin{array}{c}-0.81_{\star \star * \star}^{* * *} \\
(0.21)\end{array}$ & $\begin{array}{c}1.45^{* * *} \\
(0.47)\end{array}$ & $\begin{array}{c}2.81_{\star}^{* * *} \\
(0.95)\end{array}$ & $\begin{array}{c}1.15^{* * *} \\
(0.49)\end{array}$ & 0.38 & $\begin{array}{c}165 \\
{[0.00]}\end{array}$ \\
\hline Finland & $\begin{array}{c}0.80^{* * *} \\
(0.22)\end{array}$ & $\begin{array}{c}0.81^{* * *} \\
(0.12)\end{array}$ & $\begin{array}{c}0.64_{\star \star \star \star}^{* * *} \\
(0.09)\end{array}$ & $\begin{array}{c}1.10^{* * *} \\
(0.18)\end{array}$ & 0.63 & $\begin{array}{c}253 \\
{[0.00]}\end{array}$ \\
\hline France & $\begin{array}{c}0.95^{* * * *} \\
(0.10)\end{array}$ & $\begin{array}{l}0.41_{\star \star} \\
(0.27)\end{array}$ & 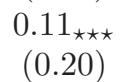 & $\begin{array}{c}0.83^{* *} \\
(0.39)\end{array}$ & 0.35 & $\begin{array}{c}224 \\
{[0.00]}\end{array}$ \\
\hline Germany & $\begin{array}{c}0.47_{\star \star \star \star}^{* * *} \\
(0.13)\end{array}$ & $\begin{array}{c}0.36_{\star \star \star \star}^{* *} \\
(0.16)\end{array}$ & $\begin{array}{c}0.41_{\star \star \star}^{* *} \\
(0.16)\end{array}$ & $\begin{array}{c}0.13_{\star \star \star \star} \\
(0.30)\end{array}$ & 0.17 & $\begin{array}{c}245 \\
{[0.00]}\end{array}$ \\
\hline Greece & $\begin{array}{c}0.82^{* * * *} \\
(0.20)\end{array}$ & $\begin{array}{l}1.08^{* *} \\
(0.39)\end{array}$ & $\begin{array}{c}1.28^{* * *} \\
(0.39)\end{array}$ & $\begin{array}{c}0.81^{* *} \\
(0.39)\end{array}$ & 0.49 & $\begin{array}{c}121 \\
{[0.00]}\end{array}$ \\
\hline Ireland & $\begin{array}{c}1.22^{* * *} \\
(0.15)\end{array}$ & $\begin{array}{c}0.91^{* * *} \\
(0.31)\end{array}$ & $\begin{array}{l}0.93^{*} \\
(0.50)\end{array}$ & $\begin{array}{c}0.88^{* * *} \\
(0.32)\end{array}$ & 0.39 & $\begin{array}{c}149 \\
{[0.00]}\end{array}$ \\
\hline Italy & $\begin{array}{c}0.88^{* * *} \\
(0.19)\end{array}$ & 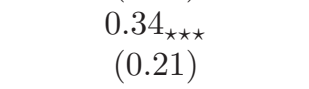 & 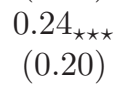 & $\begin{array}{l}1.14^{*} \\
(0.67)\end{array}$ & 0.30 & $\begin{array}{c}195 \\
{[0.00]}\end{array}$ \\
\hline Netherlands & $\begin{array}{c}0.43 \\
(0.70)\end{array}$ & 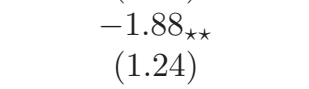 & $\begin{array}{l}-0.67 \\
(1.10)\end{array}$ & $\begin{array}{c}-7.66_{* \star}^{* *} \\
(3.22)\end{array}$ & 0.40 & $\begin{array}{c}143 \\
{[0.00]}\end{array}$ \\
\hline Norway & - & - & - & - & - & - \\
\hline Portugal & $\begin{array}{c}1.53_{\star \star \star \star}^{* * *} \\
(0.16)\end{array}$ & $\begin{array}{c}0.65_{\star \star}^{* * *} \\
(0.14)\end{array}$ & $\begin{array}{l}0.63^{* *} \\
(0.30)\end{array}$ & $\begin{array}{c}0.65_{\star \star}^{* * *} \\
(0.15)\end{array}$ & 0.44 & $\begin{array}{c}213 \\
{[0.00]}\end{array}$ \\
\hline Spain & $\begin{array}{c}0.82^{* * *} \\
(0.11)\end{array}$ & $\begin{array}{c}0.81^{* * *} \\
(0.16)\end{array}$ & $\begin{array}{c}0.63_{\star \star \star *}^{* * *} \\
(0.13)\end{array}$ & $\begin{array}{c}0.95^{* * *} \\
(0.34)\end{array}$ & 0.57 & $\begin{array}{c}169 \\
{[0.00]}\end{array}$ \\
\hline Sweden & - & - & - & - & - & - \\
\hline UK & $\begin{array}{c}1.53_{\star \star \star \star}^{* * *} \\
(0.16)\end{array}$ & $\begin{array}{l}0.74^{* *} \\
(0.27)\end{array}$ & $\begin{array}{l}0.66^{* *} \\
(0.28)\end{array}$ & $\begin{array}{l}0.87^{* *} \\
(0.33)\end{array}$ & 0.25 & $\begin{array}{c}202 \\
{[0.00]}\end{array}$ \\
\hline
\end{tabular}

Notes: This table reports the long-run (LR), short-run linear (SR linear), and short-run Markov-switching (SR MS) elasticity of the Social contributions revenue with respect to its base, along with the Markovswitching model $R^{2}$ and the likelihood ratio (LR) test statistic described in Section 2.1. The stardard errors of coefficients and the LR test $p$-value are also reported. The symbols ${ }^{*},{ }^{* *}$, and ${ }^{* * *}$ indicate rejection of the null hypothesis that the elasticity is zero at the $90 \%, 95 \%$, and $99 \%$ confidence level, while the symbols ${ }_{\star},{ }_{\star \star}$, and ${ }_{\star \star \star}$ indicate rejection of the null hypothesis that the elasticity is one at the $90 \%, 95 \%$, and $99 \%$ confidence level. 
Table 11: Elasticity of SC base with respect to GDP

\begin{tabular}{|c|c|c|c|c|c|c|}
\hline \multirow[t]{2}{*}{ Country } & \multirow[t]{2}{*}{$\begin{array}{l}\text { LR elasticity } \\
\delta^{T B} \\
\text { (s.e.) }\end{array}$} & \multirow[t]{2}{*}{$\begin{array}{c}\text { SR linear elasticity } \\
\beta^{T B} \\
\text { (s.e.) }\end{array}$} & \multicolumn{2}{|c|}{$\begin{array}{l}\text { SR MS elasticity } \\
\beta^{T B} \\
\text { (s.e.) }\end{array}$} & \multirow[t]{2}{*}{$\begin{array}{c}\text { MS model } \\
R^{2}\end{array}$} & \multirow[t]{2}{*}{$\begin{array}{c}\text { Likelihood ratio } \\
\text { test statistic } \\
\text { [p-value] }\end{array}$} \\
\hline & & & Boom & Recession & & \\
\hline Austria & $\begin{array}{c}0.30_{\star \star \star}^{* * *} \\
(0.09)\end{array}$ & $\begin{array}{c}0.27_{\star \star \star}^{* * *} \\
(0.06)\end{array}$ & $\begin{array}{c}0.29_{\star \star \star *}^{* * *} \\
(0.06)\end{array}$ & $\begin{array}{c}0.20_{\star \star \star} \\
(0.12)\end{array}$ & 0.30 & $\begin{array}{c}304 \\
{[0.00]}\end{array}$ \\
\hline Belgium & $\begin{array}{c}0.30_{\star \star \star *}^{* * *} \\
(0.09)\end{array}$ & $\begin{array}{c}0.02_{\star \star \star \star} \\
(0.10)\end{array}$ & $\begin{array}{c}-0.16_{\star \star \star}^{* *} \\
(0.06)\end{array}$ & $\begin{array}{c}0.20_{\star \star \star \star} \\
(0.29)\end{array}$ & 0.26 & $\begin{array}{c}269 \\
{[0.00]}\end{array}$ \\
\hline Denmark & $\begin{array}{c}0.70_{\star \star *}^{* * *} \\
(0.13)\end{array}$ & $\begin{array}{c}0.13_{\star \star \star \star} \\
(0.13)\end{array}$ & $\begin{array}{c}0.18_{\star \star \star \star} \\
(0.14)\end{array}$ & $\begin{array}{c}0.00_{\star \star \star} \\
(0.18)\end{array}$ & 0.31 & $\begin{array}{c}235 \\
{[0.00]}\end{array}$ \\
\hline Finland & $\begin{array}{c}0.56_{\star \star \star *}^{* * *} \\
(0.07)\end{array}$ & $\begin{array}{c}0.49_{\star \star \star}^{* * *} \\
(0.07)\end{array}$ & $\begin{array}{c}0.48_{\star \star \star *}^{* * *} \\
(0.07)\end{array}$ & $\begin{array}{c}0.41_{\star \star *}^{* * *} \\
(0.10)\end{array}$ & 0.62 & $\begin{array}{c}267 \\
{[0.00]}\end{array}$ \\
\hline France & $\begin{array}{c}0.72_{\star \star \star *}^{* * *} \\
(0.09)\end{array}$ & $\begin{array}{c}0.53_{\star \star \star \star}^{* * *} \\
(0.06)\end{array}$ & $\begin{array}{c}0.48_{\star \star \star \star}^{* * *} \\
(0.06)\end{array}$ & $\begin{array}{c}0.58_{\star \star \star *}^{* * *} \\
(0.07)\end{array}$ & 0.64 & $\begin{array}{c}312 \\
{[0.00]}\end{array}$ \\
\hline Germany & $\begin{array}{c}0.42 \\
(0.40)\end{array}$ & $\begin{array}{c}0.40_{\star \star \star \star}^{* * *} \\
(0.08)\end{array}$ & $\begin{array}{c}0.44_{\star \star \star}^{* * *} \\
(0.08)\end{array}$ & $\begin{array}{c}0.35_{\star \star \star \star}^{* * *} \\
(0.07)\end{array}$ & 0.38 & $\begin{array}{c}270 \\
{[0.00]}\end{array}$ \\
\hline Greece & $\begin{array}{c}0.88^{* * *} \\
(0.14)\end{array}$ & $\begin{array}{c}0.03_{\star \star \star \star} \\
(0.05)\end{array}$ & 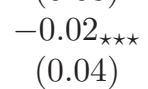 & $\begin{array}{c}0.06_{\star \star \star} \\
(0.11)\end{array}$ & 0.28 & $\begin{array}{c}144 \\
{[0.00]}\end{array}$ \\
\hline Ireland & $\begin{array}{c}1.14_{\star}^{* * *} \\
(0.08)\end{array}$ & $\begin{array}{c}0.07_{\star \star \star \star} \\
(0.16)\end{array}$ & $\begin{array}{c}0.09_{\star \star \star} \\
(0.15)\end{array}$ & $\begin{array}{c}-0.03_{\star \star \star} \\
(0.21)\end{array}$ & 0.24 & $\begin{array}{c}188 \\
{[0.00]}\end{array}$ \\
\hline Italy & $\begin{array}{c}0.88^{* * *} \\
(0.09)\end{array}$ & $\begin{array}{c}0.40_{\star \star \star}^{* *} \\
(0.15)\end{array}$ & $\begin{array}{c}0.36_{\star \star \star \star} \\
(0.22)\end{array}$ & $\begin{array}{c}0.42_{\star \star * \star}^{* * *} \\
(0.14)\end{array}$ & 0.29 & $\begin{array}{c}210 \\
{[0.00]}\end{array}$ \\
\hline Netherlands & $\begin{array}{c}0.47_{\star \star * *}^{* * *} \\
(0.09)\end{array}$ & $\begin{array}{c}0.47_{\star \star \star *}^{* * *} \\
(0.12)\end{array}$ & $\begin{array}{c}0.72_{\star \star *}^{* * *} \\
(0.13)\end{array}$ & $\begin{array}{c}0.28_{\star \star \star \star}^{*} \\
(0.15)\end{array}$ & 0.41 & $\begin{array}{c}262 \\
{[0.00]}\end{array}$ \\
\hline Norway & - & - & - & - & - & {$[0$.} \\
\hline Portugal & $\begin{array}{c}1.22^{* * * *} \\
(0.18)\end{array}$ & $\begin{array}{c}0.57_{\star \star *}^{* * *} \\
(0.20)\end{array}$ & $\begin{array}{l}0.80^{* *} \\
(0.32)\end{array}$ & $\begin{array}{l}0.48_{\star \star *}^{* *} \\
(0.22)\end{array}$ & 0.34 & $\begin{array}{c}228 \\
{[0.00]}\end{array}$ \\
\hline Spain & $\begin{array}{c}0.65_{\star \star \star *}^{* * *} \\
(0.06)\end{array}$ & $\begin{array}{c}0.81^{* * * *} \\
(0.13)\end{array}$ & $\begin{array}{c}0.79^{* * *} \\
(0.13)\end{array}$ & $\begin{array}{c}0.70^{* * * *} \\
(0.18)\end{array}$ & 0.55 & $\begin{array}{c}189 \\
{[0.00]}\end{array}$ \\
\hline Sweden & - & - & - & - & - & - \\
\hline UK & $\begin{array}{c}0.82_{\star \star \star *}^{* * *} \\
(0.06)\end{array}$ & $\begin{array}{c}0.60_{\star \star}^{* * *} \\
(0.15)\end{array}$ & $\begin{array}{c}0.42_{\star \star \star}^{* * *} \\
(0.15)\end{array}$ & $\begin{array}{c}0.82^{* * *} \\
(0.22)\end{array}$ & 0.48 & $\begin{array}{c}248 \\
{[0.00]}\end{array}$ \\
\hline
\end{tabular}

Notes: This table reports the long-run (LR), short-run linear (SR linear), and short-run Markov-switching (SR MS) elasticity of the Social contributions base with respect to GDP, along with the Markov-switching model $R^{2}$ and the likelihood ratio (LR) test statistic described in Section 2.1. The stardard errors of coefficients and the LR test $p$-value are also reported. The symbols ${ }^{*},{ }^{* *}$, and ${ }^{* * *}$ indicate rejection of the null hypothesis that the elasticity is zero at the $90 \%, 95 \%$, and $99 \%$ confidence level, while the symbols ${ }_{\star},{ }_{\star \star}$, and ${ }_{\star \star \star}$ indicate rejection of the null hypothesis that the elasticity is one at the $90 \%, 95 \%$, and $99 \%$ confidence level. 
Table 12: Elasticity of SC revenue with respect to GDP

\begin{tabular}{lcccc}
\hline Country & $\begin{array}{c}\text { LR elasticity } \\
\delta^{T B} \cdot \delta^{B Y}\end{array}$ & $\begin{array}{c}\text { SR linear elasticity } \\
\beta^{T B} \cdot \beta^{B Y}\end{array}$ & $\begin{array}{c}\text { SR MS elasticity } \\
\beta^{T B} \cdot \beta^{B Y}\end{array}$ \\
\hline Austria & & & Boom & Recession \\
Belgium & 0.24 & 0.16 & 0.15 & 0.18 \\
Denmark & -0.57 & 0.01 & -0.13 & 0.05 \\
Finland & 0.45 & 0.18 & 0.50 & 0.00 \\
France & 0.68 & 0.40 & 0.31 & 0.45 \\
Germany & 0.20 & 0.22 & 0.05 & 0.48 \\
Greece & 0.73 & 0.14 & 0.18 & 0.05 \\
Ireland & 1.39 & 0.03 & -0.02 & 0.05 \\
Italy & 0.77 & 0.06 & 0.09 & -0.03 \\
Netherlands & 0.20 & 0.14 & 0.09 & 0.48 \\
Norway & - & -0.89 & -0.48 & -2.18 \\
Portugal & 1.86 & - & - & - \\
Spain & 0.53 & 0.37 & 0.50 & 0.31 \\
Sweden & - & 0.66 & 0.50 & 0.67 \\
UK & 1.26 & - & - & - \\
\hline
\end{tabular}

Notes: This table reports the product of the Social contributions tax-to-base and base-to-GDP elasticities combined in a single tax-to-GDP elasticity for the long-run (LR), short-run linear (SR), and short-run Markov-switching (SR MS). 
Table 13: Summary of short-run Markov-switching results

\begin{tabular}{lcccc|cccc}
\hline Country & \multicolumn{3}{c}{ Larger in boom } & \multicolumn{5}{c}{ Larger in recession } \\
\hline & PIT & CIT & Ind & SC & PIT & CIT & Ind & SC \\
\hline Austria & & - & $\checkmark$ & & $\checkmark$ & - & & $\checkmark$ \\
Belgium & - & - & & $\checkmark$ & - & - & $\checkmark$ & \\
Denmark & & - & $=$ & $\checkmark$ & $\checkmark$ & - & $=$ & \\
Finland & & & & & $\checkmark$ & $\checkmark$ & $\checkmark$ & $\checkmark$ \\
France & & & & & $\checkmark$ & $\checkmark$ & $\checkmark$ & $\checkmark$ \\
Germany & $\checkmark$ & & $\checkmark$ & $\checkmark$ & & $\checkmark$ & & \\
Greece & & $=$ & $\checkmark$ & & $\checkmark$ & $=$ & & $\checkmark$ \\
Ireland & $\checkmark$ & $\checkmark$ & & $\checkmark$ & & & $\checkmark$ & \\
Italy & $\checkmark$ & $\checkmark$ & & & & & $\checkmark$ & $\checkmark$ \\
Netherlands & & - & & & $\checkmark$ & - & $\checkmark$ & $\checkmark$ \\
Norway & $\checkmark$ & - & - & - & & - & - & - \\
Portugal & $\checkmark$ & $\checkmark$ & & $\checkmark$ & & & $\checkmark$ & \\
Spain & $\checkmark$ & $\checkmark$ & & & & & $\checkmark$ & $\checkmark$ \\
Sweden & & & & - & $\checkmark$ & $\checkmark$ & $\checkmark$ & - \\
UK & $\checkmark$ & & & & & $\checkmark$ & $\checkmark$ & $\checkmark$ \\
\hline
\end{tabular}

Notes: This table reports a summary of short-run tax-to-GDP results. For each country and each tax category, the symbol " $\checkmark$ " indicates whether short-run tax elasticity is larger in boom or recession. The symbol "=" indicates that elasticity does not change across business cycle regimes, while the symbol " " indicates that overall tax-to-GDP estimates could not be obtained. 
Table 14: Data sample coverage for regression models

\begin{tabular}{|c|c|c|c|c|}
\hline Country & PIT & CIT & Indirect & $\mathrm{SC}$ \\
\hline Austria & 99q1-13q1 (57) & 99q1-13q1 (57) & 91q1-13q1 (89) & 99q1-13q1 (57) \\
\hline Belgium & - & - & 95q2-13q1 (72) & 99q1-13q1 (57) \\
\hline Denmark & 99q1-13q1 (57) & 99q1-13q1 (57) & 91q2-13q1 (88) & $99 \mathrm{q} 1-13 \mathrm{q} 1$ (57) \\
\hline Finland & 99q1-13q1 (57) & 99q1-13q1 (57) & 91q1-13q1 (89) & $99 q 1-13 q 1(57)$ \\
\hline France & 80q1-13q1 (133) & 80q1-13q1 (133) & 91q1-12q4 (88) & $99 q 1-13 q 1(57)$ \\
\hline Germany & $99 \mathrm{q} 1-12 \mathrm{q} 4(56)$ & $99 \mathrm{q} 1-12 \mathrm{q} 4(56)$ & $91 \mathrm{q} 2-12 \mathrm{q} 4(87)$ & $99 q 1-13 q 1$ (57) \\
\hline Greece & 00q1-13q1 (53) & 00q1-13q1 (53) & 00q1-13q1 (53) & 00q1-11q1 (45) \\
\hline Ireland & 02q1-13q1 (45) & 02q1-13q1 (45) & 00q2-13q1 (52) & 00q2-13q1 (52) \\
\hline Italy & 99q1-13q1 (57) & 99q1-13q1 (57) & 91q1-13q1 (89) & $99 \mathrm{q} 1-12 \mathrm{q} 4(56)$ \\
\hline Netherlands & 05q1-13q1 (33) & 05q1-13q1 (33) & 91q1-13q1 (89) & 99q1-13q1 (57) \\
\hline Norway & 02q1-13q1 (45) & - & 80q1-13q1 (133) & - \\
\hline Portugal & 99q1-13q1 (57) & 99q1-13q1 (57) & $96 q 1-13 q 1$ (69) & 99q1-13q1 (57) \\
\hline Spain & 01q2-13q1 (48) & 01q2-12q4 (47) & 01q2-13q1 (48) & 01q2-11q2 (41) \\
\hline Sweden & 99q1-13q1 (57) & $99 \mathrm{q} 1-13 \mathrm{q} 1$ (57) & 93q2-13q1 (80) & - \\
\hline UK & 99q1-13q1 (57) & 99q1-13q1 (57) & 90q1-13q1 (93) & 99q1-13q1 (57) \\
\hline
\end{tabular}

Notes: This table reports the maximum data sample range for each country and each tax category. The number of observations is in brackets. 


\section{Appendix A}

\section{Data sources and manipulation}

Personal income tax (PIT) revenue: The PIT revenue data consist of the general government receipts from current taxes on income, wealth, etc. levied on households and non-profit institutions serving households sector. We express revenues in real terms using the GDP deflator, national base/reference year, seasonal adjusted. Both revenue and GDP deflator data are from the OECD database. PIT revenue data for Belgium are unavailable, while those for Greece are used in nominal terms due to the national deflator unavailability.

Personal income tax base: The PIT base is obtained as the sum of gross operating surplus and mixed income, compensation of employees, property income and gross entrepreneurial income of the households and non-profit institutions serving households sector. We use the GDP deflator to obtain deflated data. Data are taken from the OECD database. As for revenue, the PIT base data for Belgium are unavailable, while those for Greece are in nominal terms.

Corporate income tax (CIT) revenue: The CIT revenue data consist of the general government receipts from current taxes on income, wealth, etc. levied on corporations (both non-financial and financial), deflated using the GDP deflator. Both series are from the OECD database.

Corporate income tax base: the CIT base is given by the sum of the gross operating surplus and mixed income, property income, and gross entrepreneurial income, deflated using the GDP deflator. Both series are from the OECD database.

Indirect tax (IND) revenue: General government indirect tax receipts, from the ECB database. Seasonal adjustment is obtained using TRAMO/SEATS. We obtain deflated revenue data using the private final consumption expenditure deflator in the na- 
tional base/reference year, seasonal adjusted, taken from the OECD database. Indirect taxes of Belgium and Greece are in nominal terms due to the national deflator unavailability. Norway's data on indirect tax revenues are unavailable.

Indirect tax base: Chained volume estimates of private final consumption expenditure, in millions of national currency, national reference year, seasonal adjusted, taken from the OECD database. Exceptions are Belgium, for which chained volumes data are unavailable and we must resort to current prices data, and Greece, for which we use current prices data to match nominal data on revenue. Data for Greece, moreover, are not seasonal adjusted at source, so that we use TRAMO/SEATS to adjust them.

Social contributions (SC): General government social contributions, from the ECB database. Seasonal adjustment is obtained using TRAMO/SEATS. The series are expressed in real terms using the GDP deflator. Social contributions of Greece are in nominal terms due to the national deflator unavailability. Norway's data on social contributions are unavailable.

Social contributions base: Gross wages and salaries, seasonal adjusted and adjusted by working days, at current prices in millions of national currency from the OECD database. Data are expressed in real terms using the GDP deflator, except for Greece due to the national deflator unavailability. Norway's and Sweden's data on gross wages and salaries are unavailable.

GDP level: Chained volume estimates of gross domestic product in millions of national currency, national reference year, seasonal adjusted at source, OECD database. Exceptions are data for Greece, seasonal unadjusted at source.

GDP growth rate: Real GDP growth rate compared to previous quarter, seasonal adjusted, from the OECD database. For Greece, we computed the GDP growth rate from the chained volume estimate level seasonal adjusted using TRAMO/SEATS.

Tax policy changes dummies For each country and each tax category we codified a quarterly dummy variable that takes value 1 in quarters when a tax policy change took 
effect and zero otherwise. To overcome concerns about the comparability of tax reforms classification methods, we relied on information collected and processed by the European Commission in the annual survey of taxation trends in the European Union. ${ }^{14}$ Being the survey conducted by the European Union country policy analysts, we can be sufficiently confident that uniform criteria and methodology for reforms classification and dating are followed. One further advantage of this source is that we avoided getting stacked in minor changing details of national tax systems because the European Commission only reports major reforms. As for time alignment, we entered the value 1 only in quarters for which the European Commission's report clearly indicates the month when the reform was implemented and took effect. When the reform was adopted within the annual budget law, the dummy takes value 1 in the first quarter of the year following the budget approval. If only the year is reported, we entered a value of 1 for each and every quarter of that year.

\footnotetext{
${ }^{14}$ See all report issues available at http://ec.europa.eu/taxation\_customs/taxation/gen \_info/ economic \_analysis/tax \_structures/article\_5171\_en.htm
} 


\section{References}

Barrios, Salvador and Raffaele Fargnoli, "Discretionary measures and tax revenues in the run-up to the financial crisis," European Economy Economic Papers 419, Directorate-General for Economic and Financial Affairs (DG ECFIN), European Commission July 2010.

Bettendorf, Leon and Duncan van Limbergen, "The stability of tax elasticities in the Netherlands," Technical Report, CPB Netherlands Bureau for Economic Policy Analysis September 2013.

Boschi, Melisso, Stefano d'Addona, and Aditya Goenka, "Testing External Habits In An Asset Pricing Model," CAMA Working Paper 20/2012, Centre for Applied Macroeconomic Analysis 2012.

_, _, and Maria Rosaria Marino, "The stability of tax elasticities over the business cycle in Italy," 2017.

Bouthevillain, Carine, Philippine Cour-Thimann, Gerrit van de Dool, Pablo Hernández de Cos, Geert Langenus, Matthias Mohr, Sandro Momigliano, and Mika Tujula, "Cyclically adjusted budget balances: an alternative approach," Working Paper Series 0077, European Central Bank September 2001.

Brondolo, John, "Collecting Taxes During an Economic Crisis: Challenges and Policy Options," Staff Position Note 09/17, International Monetary Fund July 2009.

Bruce, Donald, William F. Fox, and Mark H. Tuttle, "Tax Base Elasticities: A Multi-State Analysis of Long-Run and Short-Run Dynamics," Southern Economic Journal, 2006, 73 (2), 315-341. 
d'Addona, Stefano and Ilaria Musumeci, "The British opt-out from the European Monetary Union: empirical evidence from monetary policy rules," Applied Financial Economics, 2013, 23 (23), 1783-1795.

Girouard, Nathalie and Christophe André, "Measuring cyclically-adjusted budget balances for OECD countries.," Economic Department Working Paper 434, OECD 2005 .

Gómez, Victor and Agustín Maravall, "Programs TRAMO and SEATS, Instruction for User (Beta Version: september 1996)," Technical Report 1996.

Hamilton, James D., "A New Approach to the Economic Analysis of Nonstationary Time Series and the Business Cycle," Econometrica, March 1989, 57 (2), 357-384.

Johansen, Soren, Likelihood-Based Inference in Cointegrated Vector Autoregressive Models number 9780198774501. In 'OUP Catalogue.', Oxford University Press, April 1995.

Jooste, Charl and Ruthira Naraidoo, "Nonlinear Tax Elasticities And Their Implications For The Structural Budget Balance," The Journal of Applied Business Research, 2011, 27 (4), 113-125.

Kim, Chang-Jin and Charles R. Nelson, State-Space Models with Regime Switching, Cambridge and London: MIT Press, 1999.

Koester, Gerrit B. and Christoph Priesmeier, "Estimating dynamic tax revenue elasticities for Germany,” Discussion Paper 23/2012, Deutsche Bundesbank 2012.

Larch, Martin and Alessandro Turrini, "The cyclically-adjusted budget balance in EU fiscal policy making: A love at first sight turned into a mature relationship," European Economy, Economic Papers 374, European Commission December 2009. 
Mourre, Gilles and Savina Princen, "Tax Revenue Elasticities Corrected for Policy Changes in the EU," European Economy Discussion Papers 018, Directorate-General for Economic and Financial Affairs (DG ECFIN), European Commission November 2015.

_, George-Marian Isbasoiu, Dario Paternoster, and Matteo Salto, "The cyclically-adjusted budget balance used in the EU fiscal framework: an update," European Economy, Economic Papers 478, Directorate-General for Economic and Financial Affairs (DG ECFIN), European Commission March 2013.

Newey, Whitney K. and Kenneth D. West, "A Simple Positive Semi-Definite, Heteroskedasticity and Autocorrelation Consistent Covariance Matrix," Econometrica, May 1987, 55 (3), 703-708.

Perotti, Roberto, "Estimating the effects of fiscal policy in OECD countries," Proceedings, Federal Reserve Bank of San Francisco, 2005.

Poghosyan, Tigran, "Assessing the Variability of Tax Elasticities in Lithuania," Working Paper WP/11/270, IMF 2011.

Prest, Alan R., "The sensitivity of the yield of personal income tax in the United Kingdom," The Economic Journal, September 1962, 72 (287), 576-596.

Princen, Savina, Gilles Mourre, Dario Paternoster, and George-Marian Isbasoiu, "Discretionary tax measures: pattern and impact on tax elasticities," European Economy - Economic Papers 499, Directorate-General for Economic and Financial Affairs (DG ECFIN), European Commission May 2013.

Ramey, Valerie A. and Matthew D. Shapiro, "Costly capital reallocation and the effects of government spending," Carnegie-Rochester Conference Series on Public Policy, June 1998, 48 (1), 145-194. 
Romer, Christina D. and David H. Romer, "The Macroeconomic Effects of Tax Changes: Estimates Based on a New Measure of Fiscal Shocks," American Economic Review, June 2010, 100 (3), 763-801.

Sancak, Cemile, Ricardo Velloso, and Jing Xing, "Tax revenue response to the business cycle," IMF Working Paper 10/71, International Monetary Fund March 2010.

Sobel, Russel S. and Randall G. Holcombe, "Measuring the Growth and Variability of Tax Bases over the Business Cycle," National Tax Journal, December 1996, 49 (4), $535-552$.

Stock, James H. and Mark W. Watson, "A Simple Estimator of Cointegrating Vectors in Higher Order Integrated Systems," Econometrica, July 1993, 61 (4), 783820.

Wolswijk, Guido, "The short- and long-run tax revenue response to changes in tax bases," Economics Bulletin, August 2009, 29 (3), 1960-1970. 